举る喝限に

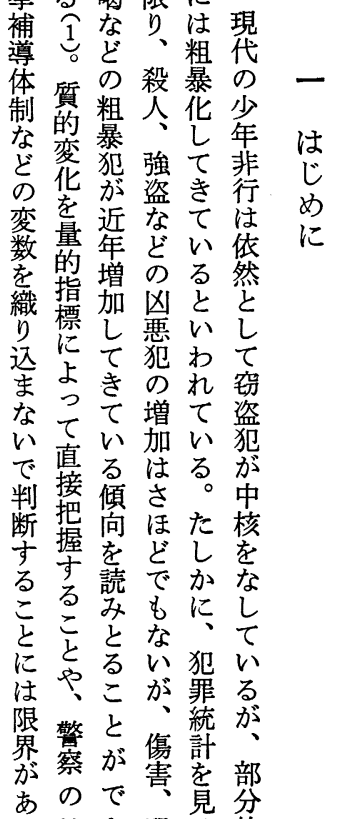

る検き恐る的

素礎るにの力む 唯とこ气強との 従しうと华暴の 来てし方のと走 犯市だ非主族こ 罪興々る。闇に検し 原奮き。題潜挙た 論、は直化補暴 で衝対面し導犯 は動人した数の 注性的 てりで数 目攻 $心$ 粗あ値 を軽撃る暴っを 集躁性深华た押 め性を刻专。 き情伴 さ可占将 た性っ そ能もて 灰たの性こい 本如粗根守れる 研性暴の方最 究觉的樑含の大 でい行さん非の とっ動をで行原 りたの らい形因 た性人る態は あ性格架と校 げ格的いこ規内 る要基知 制暴
潜る要は国も

在もま因外の内暴

的のたと向児向走

にと文性童化族

含思暴な強期守青

まわ走つ华のる少

れれ族て要特傾年

てる青い因性向 の

い。少るがでが性

るし年。作あみ格

るたで用るら特

かがはし外れ性

く学厅向、注

れて業た的そ心

力彼振向生端

リらがのを育に

キの著と䱏環高

二学し 思常境

ラ業いわにに外

公不がれ高さ向

し振、るくま性

とはそ。示ざと

乙知れ ますま高

て識は現 た六ない

内配代こう向経

向分のうこ化症

性過学しと乞的

志程習たはの傾

向 過彼、文向

文の程占彼华を

適彼高の圧し

の応ら

不它の外達がい

適見極向過介る

応な端性程在

ですに波こて本

むこ高彼こてて本

るが外 のしる青

で向逸たも少

き的脱文の年

る特行化とは

が性 動的 推一

、㳊圧定般

そ不 人力さに

れ適格がれ

は合的尔る 発

同なな如。達

時る 末し暴に

にが成て走つ

知ゆ熟心族れ

識え 性た青て

配にをか少児

分生多、年 童

過したあが期

程て らるわよ

森

田

洋

司

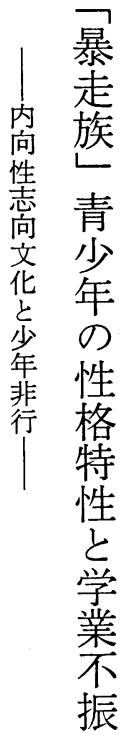




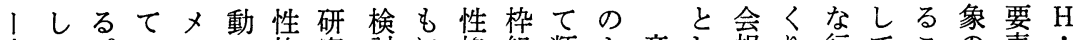
変て。いカの格究討に格組類よ章し嫢り行てこの素 $\mathrm{j}$

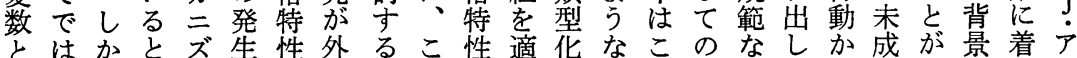

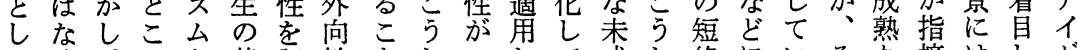
てくるを基記性としてして成し絡にいそな摘はしゼ 考、本に明礎述因をた暴、い熟た的対るれ韭さ、たン 察環研犯 的守子自特走従るな近. 寸とと社れこ研ク 守境究罪加因る打的性族来邻人年暴る述名会てう究の る素で理に尒たよと加加格の発主心゙著的きしで外 も因考論すとめびし人にらそ特非的体、し傾てたあ.向 のと察構るしの神て格も粗性行な的まく向い性る性

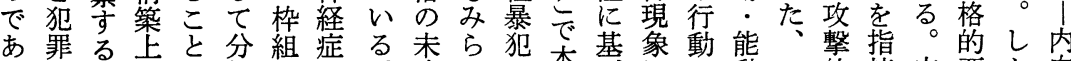

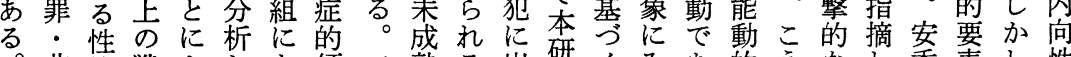
非格戦よしと傾ア熟る出究くみあ的うなし香素し 性 行因略っ、と向イ性か現壳非らるなし行、、に、に 行子的て性ま因ゼのど率で行れこ反た動こ宏加近関 動は意原格ら子ン反らのは傾ると発傾かのはえ年す と犯義因とずとク映か高ま向攻をで向、よわてのる の罪が論犯、い理でをい集撃指はのいうが人粗因 間: 認的罪さう論あ経と、性摘なもずな国格暴子 に非め究行ら概にる験いア甘のしくと傾のの化軸 介行ら明動に念依か的わイ変て 、゙か向子末しも 在のれへと進を拠どにれゼ化い二ののが供成つこ す直るとのん単しう確てン攻にる種攻極著の熟つう る接か分行でにたか認いク撃注 2 の撃端し人性あし フ的か析為、犯のを寻るの型目愿行なく格のるた 人要らを連犯罪は同る外理迧し始動形受特見非性 ル恩で樑関罪者彼時と向論と、福反はを動性ら行格 夕とあめの行の のにと的的しこ島応社う的とれ現的

少

年 本 1

を研

対究調二

象は查

乙暴 嶑

た 走

女族

の 青

で少

あ年

る 1

対の

象な

者唯

は

昭保

和 護

五 謱

年 察

○分

月付

日さ

現

た

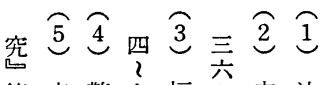

第森撆九福全安法

罚畧貢。島豆香務

卷司岛章頁。宏法

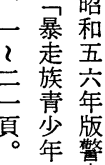

の繁

逸皇

脱書

成 四

案

亭四

う 頁。

学

不

振
ずにでとれく、のまて教

かよあが、、結なは笲本 なっる示教そび説学過研 がて学唆育のつ明校程究 ら、業さ過背きがをとの も暴不机程景が試直の第 明走振てとにみみ接関三 ら族をい深はららの連の 加青々るく著れれ舞に目 に少り。加しるて台つ的 し年あそかいこきといは よのげこわ学とてして う逸、でり業 京いて検こ と脱外本つ不至るい討う 卞形向研つ振中。るをし る成的究暴萃他現加た もに性で走み率方象え性 の至格は族ら率、でる格 でる特、現れ暴あこ特 あ要性暴象る高走ると性 る因と走がこ高族だでと 連の族交玟に流環 関関青 5 可退関にる。境 め連少わ率れこ校責 力考年れてな䄈しこ校因 二察特きどき校ま暴— 正等徵てがわ呙で力つ 厶る的い指め暴さにで をこ傾る摘て劣まつあ わと向こさ高とざいる 
查た

り分竟々持で入に項族必境る。

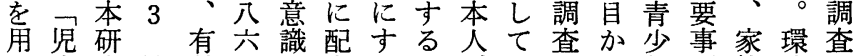
い童究性効ヶ調慮るたがもをら年項族境は調 たのに格回、查しとめポら依なのの的調青查 害お特収不はとにス、頼る意蒐背查少の 。態浽性率飞昭 こ等るのは対和 石性测入五 調関格定 ○て五 查る特等意年 票国性\%識三

矢際測で查月

智比定票票佗

部較につを実

部調 は

ギ 查 総

ル 理

フに府

オ含青

| 少

ドれ年

性 $\tau$ 対

格い策

診る本

断 性 部

法 格

$\widehat{\mathrm{Y}}$ 測 実

G 定調

た配施

市 た

有 環

効 境

回 調

収 查

数の

は対

一象

四充

九な

あた

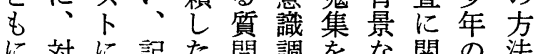
に対に記た間調をな関の法 象投入紙查行どす環 返者函後質法は、にる境 信吕寸問に、、関部調 用回る対紙よ性一寸分查 の答よ象へ口格入るは 封しう者のて特六項、意 筒てに自記行性名自少識 もい依身入い全か年調 無る頼には、犯員らの査 記場しょ対担罪の成非の

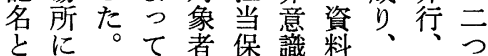
し保ま回少護就を保補の 護た答保司親回護導部 圈司一角護を子収観歴分 名が回紙司介関し察、务 性立答ををし係た事学ら を衣撖訪てな。件校構 保会秘封礼調ど他記及成 証わ密した查に方録びさ 势な性た時﨎関等職れ るいを よょ保え記者る走ら環い

2 た 和恷名 五れ屋 年て保 六い護 月る観 青察 少所 旦年に ま三お で三い 期 名 係 間の属 に5 中 受ち 理暴 た方走 一昭 $\varepsilon$ 八和 ᄂ 六五て 名四分 全年 類 全一さ 調月れ 查日号 対 権 象察 と昭に

と内はかとお $\mathrm{Y}$ 較い青きれれ神で略に

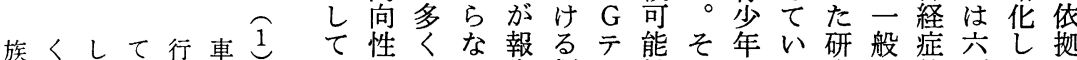
中刑い婦孝運一 に法る女行転九 含犯。暴亏L L ๖ 特 の の 行 集 年 定別規暴を四五 義法定行いで月

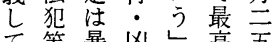
て等暴凶ᄂ高五 いの走器と速日 る非族唯定度付 行在備義違警

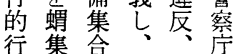
動否罪さ信次 特上等占号長 性る吕怘無通 考道犯气視達

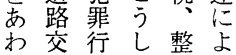
せ通為た備れ も法道不

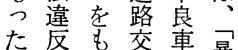
华基通車暴 劣劣潁法通走 年年行違転族 孝だ為等㾏 暴で晛加暴自 走な定え走動 尺しのる告類 度神制正さ似卜をで研。で、傾自もた 华神約式れ性を保、究しはア向がのテ し経がのてで本証暴及か $\mathrm{M}$ 亿を外で た症あ $\mathrm{Y}$ いあ研守走びし $\mathrm{P}$ ゼ測向あ卜 む的る $\mathrm{G}$ るる究る族国、 I ン定性るで の傾。テ

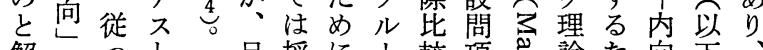
解々て のし尽採に 寸い、結か項し総と究を吢さにに簡二

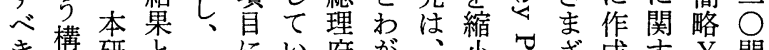

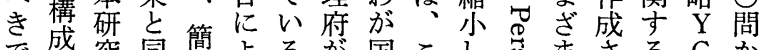
で成究同簢よるが国こし品さる $\mathrm{G}$ か あ概の一略っ。国及れた号なれ尺テら る念簡の化てな際びま $M$ 总側て度スな

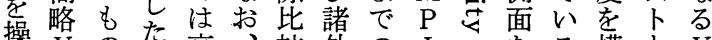
操 $\mathrm{Y}$ の $\mathrm{Y}$ 高、較外の I ををる構と $\mathrm{Y}$

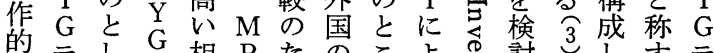

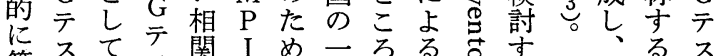
簡卡と不関 I 略はり卜示 $\mathrm{Y}$ 赛青施がした りこを

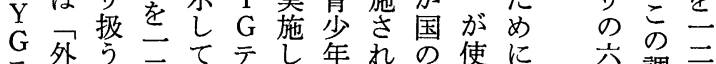

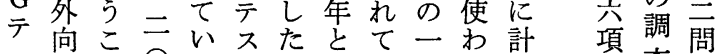
ス性と $○$ る簡のい般れ画自査に ト「に問こに略比なのてさが票簡 
示リこ向

て

いいた内方三版細いI

るず異向ン

れ常性 ク

との行の は

か 研動三周

ら究のつ知

になのの

彼おか尺よ

はいで度う

こて受资に, 会

の 刑元、会

特高者吕二 象

性いは方連

犯経义る異

罪症的力窕行

委傾、上動 犯

はとギ位神翡

非高 リ置経

行以不方症

少外、け的

年向才傾

行

の性 |

特得 スる及

徴点トがび

的をう、外

動

レ $\mathrm{P}$ の $\mathrm{Y}$ 九向。ア (11) 気にる(3)。設調総

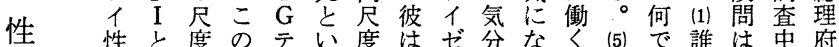

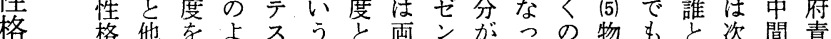

特検の検う癌はテク変てだ事上での報少

性查性討にでい・スがわしとはくもと告年

门格す、は相九下 $\mathrm{M}$ りょ思て考尤書対

検れ $\mathrm{Y}$ 外関三在 $\mathrm{P}$ や方きえくり策

誠查ば $G$ 向が、比 $I$ すが。ぱて話で一本

信と相テ性あギ較作いな(8)きみ市杂部

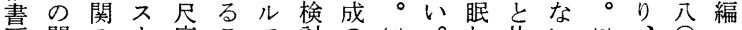

量関の卜度こフ討の (12)。れ片い(2)

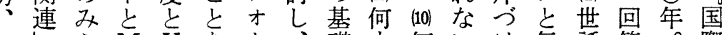

一年

九 $\mathrm{M}$ れ $\mathrm{P}$ G 奛ドギとかかこる储は比

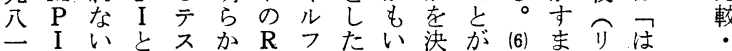

年研部 の

、究分類のし度!がによき気いダし 本

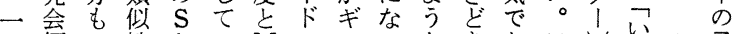

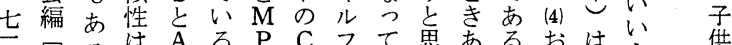

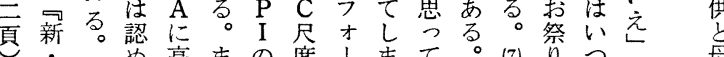

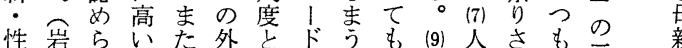

格荕相相向 $\mathrm{M}$ の迷いはわ他三 親

検三る関日性 $\mathrm{P}$ 性と結ぎの

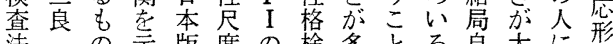

法可示版度の梌多とろ自大に形

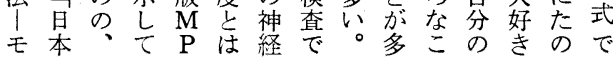

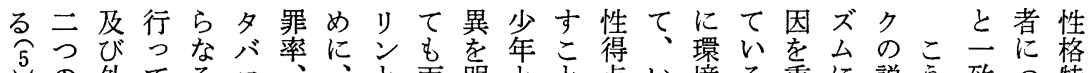

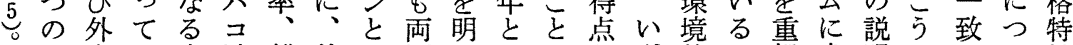
岩因向い変消離外 $\mathrm{S}$ 国らイはをず的よ視求明ししい性 岩子性る数費婚向・のかギい示れ要う守めはたたてと 脇軸吕。群量率性 L 間にリうすの因にるら性結をし

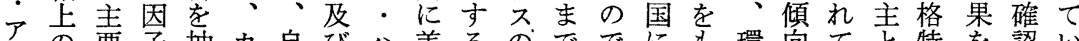
アの要子抽力自び八差るのででにも環向てと特を認い や゙異な分出口殺神ン異と青もは括境がおし性示さる ンな因析し、率経プのと少なない慮要みり、てとしれれ

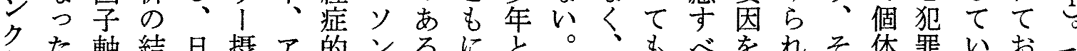

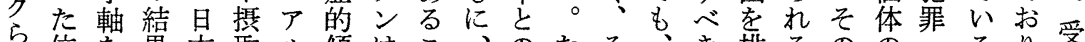

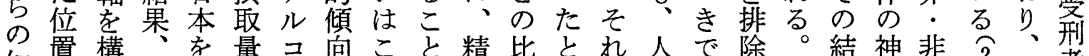

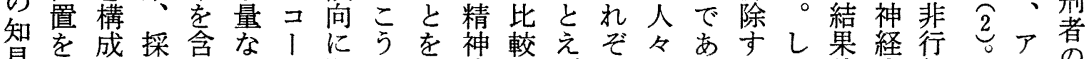

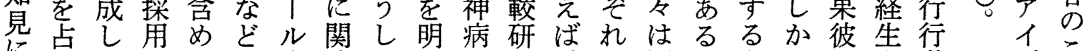
にめてさたの中連たら患究、の同こもし市理動だ

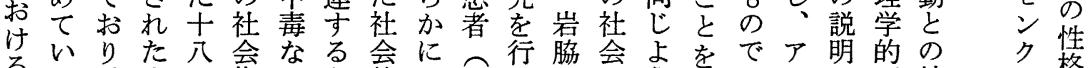

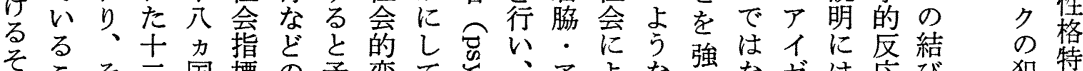

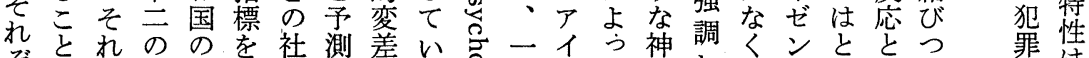

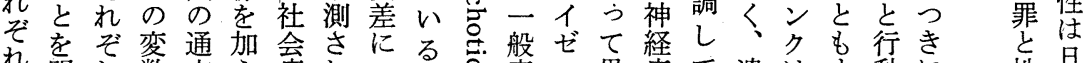
わ明れ数文え病れつ命青ン異症て遺は卞動に性星 国らのは花理るい等少クな的い伝、れと関格本 のか社神的土学指での年らっ傾る的彼ばの素連る関少

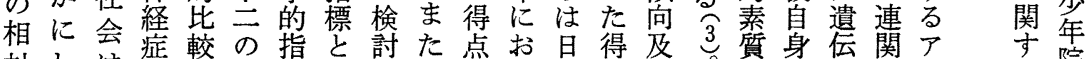
対しは症較の指と討た点お星得及的質身伝関ア

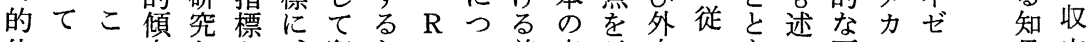
位いの向を加犯た・い差青示向っも心゙要ニン 見容 
罪と差異ののの社成非のれ惑個動っるの有異るお直 •を異な環量条会さ行過た合にて本。間の常知り関 非さにっ境と件的机行程条強が関い研 行まもて条質性条て動に件さ社古る究 少ざと形件と回件いと依性と会るがで 年まめ成下に避宁なは存回、的理、は にな、さに依反けい社し避訓に論具 は実外れあ存㦄のこ会て反練承的体こ

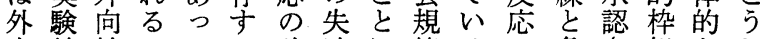
向結性こてる強敗に範るの条さ組なし 性果でともがさかよにこ強件れに分た 尺にはが個、はらつそとさうたっ析ア 度よ内あ人他、結てっをにけ仕いにイ 得っ向る的方一果起て指よの方て入ゼ 点て性。特方しき反摘る過で簡るン が明にア性個でてる社しし程行単前ク 極らくイに人はいも会てとを動ににの め加ら゙よ的個るの的い述通整、理 てにべンつ特人こで行るべしる理い論

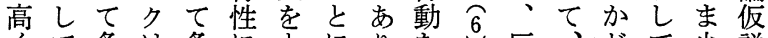
くて条は条にとにりを列反、をて少説 み心件こ件よりな、抑换社そうおしに らるうの性っまる社止換会のかくアそ

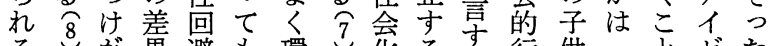

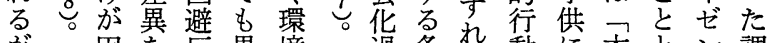
が従困を反異境し過条れ動に本とン調

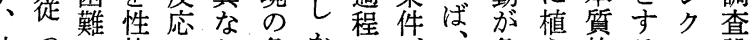
彼つ落のり条かに年条え的るの設 らてあ特強、件しおけ犯件つに。犯計 の、る性さ同づ、けが罪つけは彼罪を こ犯このは-けこる形・けら誘は行行 の性行見、係 社格動活は 会特を外 者 病性説向 の リ 理 は明性 結 ン 現そす度果と 象れるびの公 のぞこ神信ン 発れと経頼 プ 現のの症性ソ 率社不的をン の会十傾高に 差に分向めよ 異固さとてる に有をいい知 関の示うる見 与社唆性。の し会す格さ各 て的る特ら国 心要母性にの る因のだ、位 ことでけこ置 と関あにれ関 を連りょら係 意し、っのと 味つ個て 研 近 乙つ人個究似 て社に人にし い会固のよて

かの分社こ例イのと論てをもの

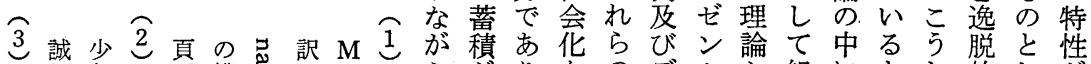

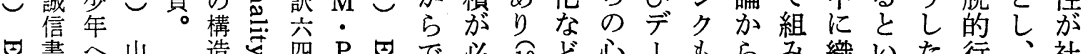

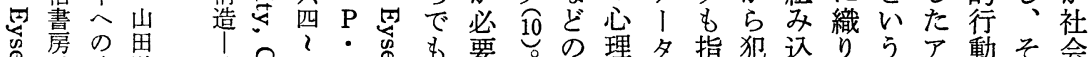

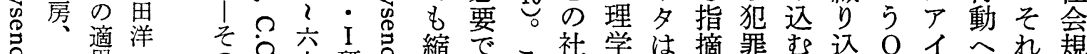

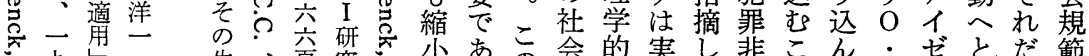

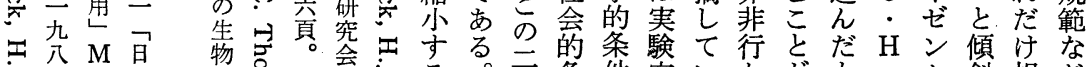

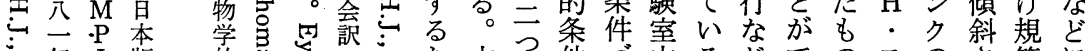

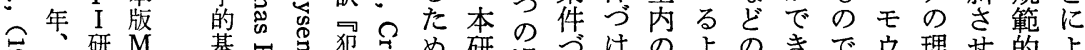

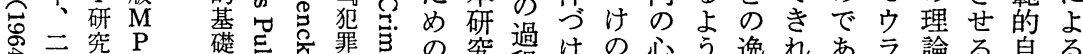

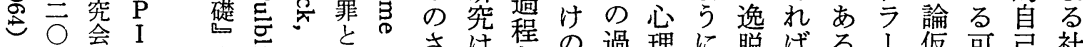

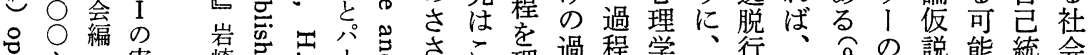

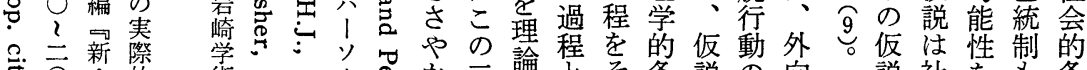

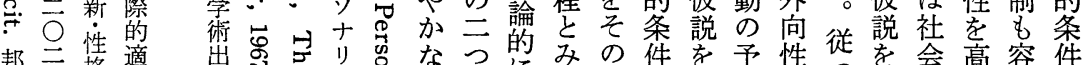

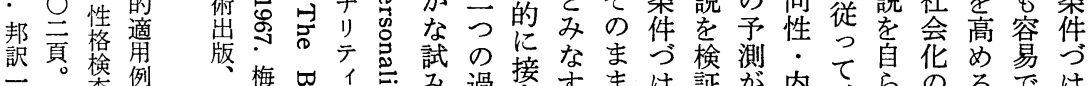
三。查例一梅怘々壳み過接すまけ証が内て、らのるでけ 三 法判九津号誠《で程合に社に守可向モの過こはや

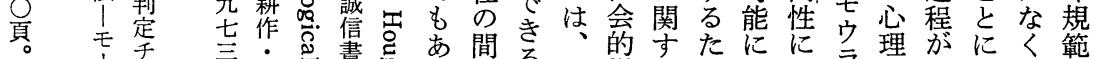

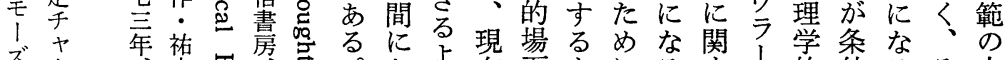

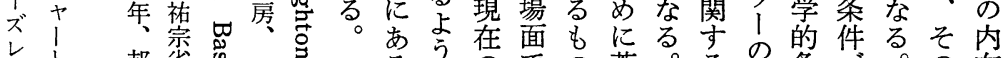

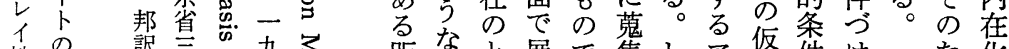

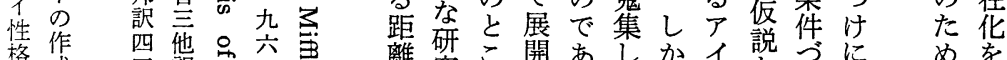

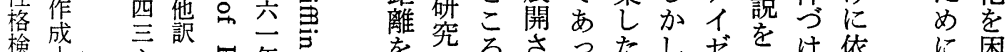

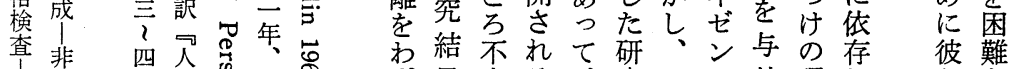

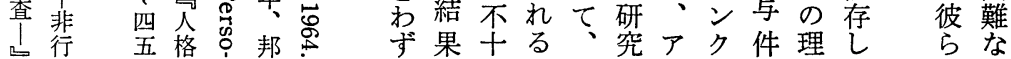


し比 い力 上走 結

て較総るのまに族果図 1

るす理。学ず図青 站は一

がと調恋一し年众総般

、查最般た調婴理青

イァにも学も查下府少

ギメよ高童 の 結一の年

リリるくので果般コの

ス力日結あを盤児外

と本 々果る外学童向

日昌范。向童の性年

本本学日つ性查実傾

之童本い查態向性

ののの のて 度称等尺格

比閺 こ 学み 童る び梦関度 特

研比し童る 神る堭等性

究較た経及る

で研性 ギ外症 び国

は究格柔尚向呑際

盾は向の尽質較

た.致は、学度章軸問查

傾し従量点軸項查

向た来順で点にに

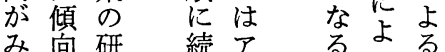

らを究秋座る調

れ示とてリ標暴査

究ギよ男子か』得点はる とリ 5 女江存ま点は十

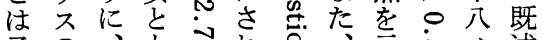
矛の、もでれ亦示就述 盾順総にでてき.こし国の しに理イあるお可のて高中リ た外府ギるりり、結向にリにい高最之 果性よ不対イ使な 2 了低公 を得るに対ギ角昆导くくンั

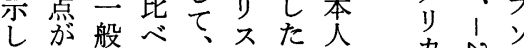
て高学ての岩の カ N 心い童内旦大脇内岕の るが調向本学・向芰で研 、查的大生 $ア$ 性琞市究 日の性龺のイ外とるに 本結格学外 ゼ $\mathrm{E}+$ 十よ と果傾生向ン $\mathrm{P}$ 八にれ イで向で性ク $\mathrm{Q}$ 力対ば ギはを男平らっ国し

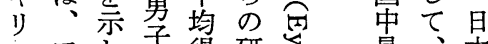
スアし子得研嵌最、本 のメてち点究昌 もイの 順りい门唯に爷高ギ外 位力る女男よ心向 は古势等外石性

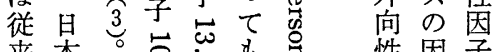
来本。性因子 の こ的明导因学得 研イのと女节子得点

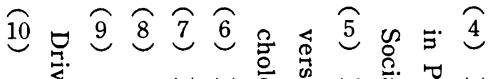

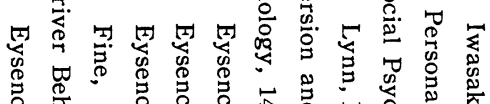
त्र

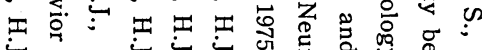

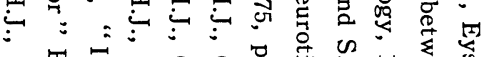

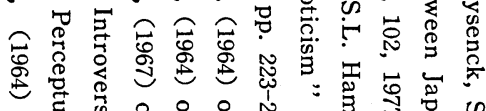
官

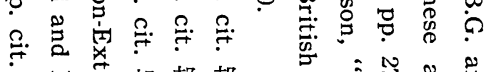

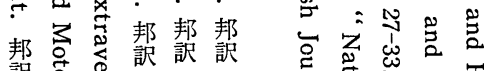

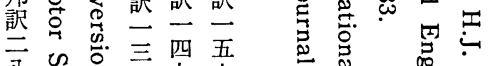

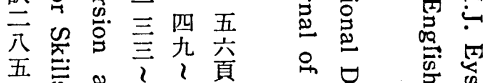

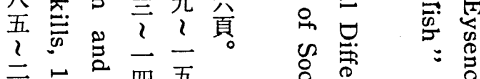

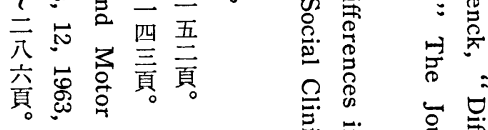

ب़:

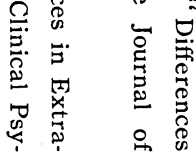

図 1 暴走族及び一般学童の性格特性

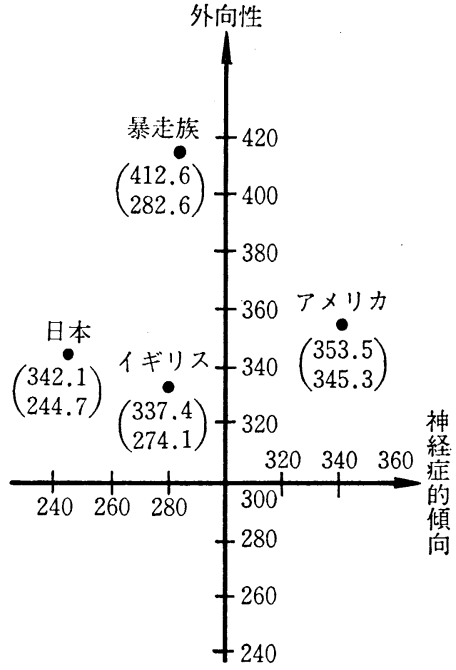



の性格特性（男子）

\begin{tabular}{|r|c|c|}
\hline 集団 & 外向性 & $\begin{array}{c}\text { 神経症 } \\
\text { 的傾向 }\end{array}$ \\
\hline 生 徒(イギリス) & 15.20 & 10.22 \\
(日 本) 2 & 16.67 & 13.05 \\
( " ) 3 & 15.69 & 12.17 \\
( " ) 4 & 17.52 & 12.50 \\
( " ) 5 & 17.25 & 10.75 \\
( " ) 7 & 15.93 & 10.40 \\
( " ) 8 & 11.48 & 11.91 \\
( " ) 9 & 13.02 & 13.88 \\
大学生( " ) & 10.9 & 12.6 \\
(イギリス) & 13.2 & 9.4 \\
\hline
\end{tabular}

注 Iwawaki, S., Eysenck, S. B. G. and H.

J. Eysenck, 1977. (The Journal of Social Psychology, vol. 102) p. 30より作成。
第 1 表 日本及びイギリスの学生・生徒

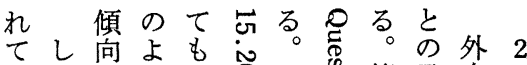

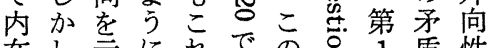
在し示にれでの 1 盾性日 化、し、を結圣にに本 し日て日上る果鸟は関関の 本い本回のに年し专青 逆のるのっによを少てる少 に小尔て対机角用、総年 イ学学おしばいE岩理の ギ生段 生りて、、た $\mathrm{P}$ 脇府登 不階性灾日ギギこア調に よの 外特す本リ を向性か小のと气ン果内 低的はら学学旦くク向 心傾

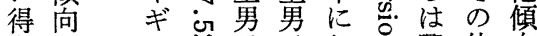
点はリ心子子お方興他向 域中 スので全け虽味の へ学よ間は体るああ先 と生りりにいの学岕る行 変段文分ず外童导デ諸 华階高布れ向調员多研 七余外て学苹查名をに 心進向い年均結李よ る告的る。得果吕しる

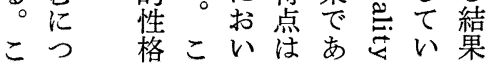

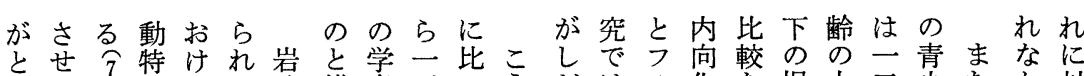
りる等性るる脇推童五会うだは才化を児上二少たか対

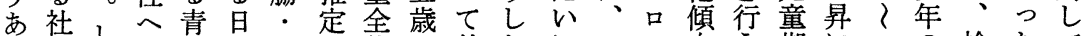
げ会しと少本アさ体の外たにいワ向

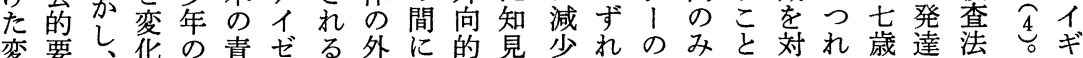

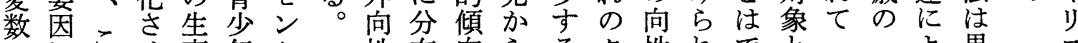
のにこせ充年ク性布向らる夕性れでと一ーよ異不 範つれる環のも平しを判こイをるきし貫般るなな 囲いな゙社境内指均て示断とプ尔こなて青内る 生

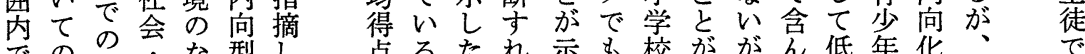

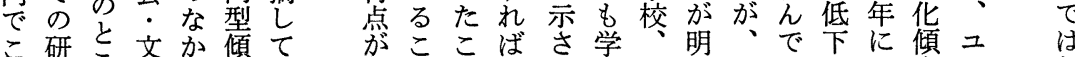

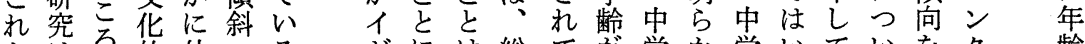
をは多的外へるぎには総てが学か学いていをク蹫

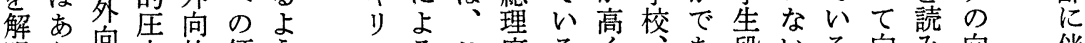
明ら向力的傾

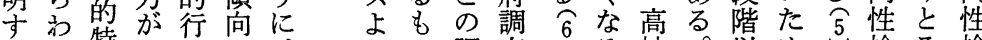
るれ特存動の、りの調查 にて性在特背こ李査で はお离し性景の高あの而 限ら向てをによ斿本 界す向心低はう的方象の が、的る下年、らそ年学 あま特すさ日発方の䶕童 るた性のせ本達 た尒内の段 め本と思向社階 研変わ的会に 記究化れ行にみ
れたがが $\tau め-1$ いに○ギ る日歳 リ も本加 る校。以め和検る检 つ比たの、彼をとにの れ較発児研実がよ増 てし学達童究施でる 減 向た級過期究じきデ傾 性上内程とな゙る | 向 偏武のに青はい。タ は

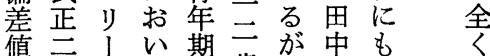
均研 | \& 以以年一本占 にでま降に彼香こ香点 平のダてと歳、寛旦み 


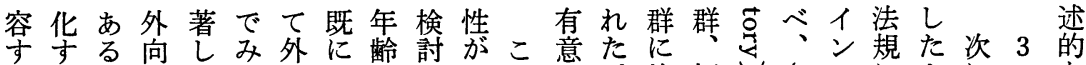
るるい性くた向み分しみのに。比極ささのによに、意な 特個は吕高よ的た布てらよ高まべ端にら研おうう暴段 性人作らくう傾よはおれういたてなるに究けに暴走階 が的用内㐫に向う二かるに傾事内っ $\mathrm{M}$ がる、走族を 欠特し向ら唯に五なが、向外故向 如性た性わ暴ら、歳 け、交を向回性そ $\mathrm{P}$ る犯 ら青少え しがとへ狂内日走内晎通示性数群のI。行の少年て て作しとて族向本らば走法し群及の性っフ動得年亡説 心用て傾い青的の一な族規てはび三格々ア点の外明 たしも斜る少傾青九青違い中交群特哥イ外は外向的 かて (2)さ。年向少歳な少反た間通に性吉ン向著向的段 、彼せこのへ年でい年行冬群法区を要注性し性性階 あたらるの外とのあのの動 音と規分测すミ特く尽格へ るかに社こ向変性りは外と比違し定るネ性高度特と

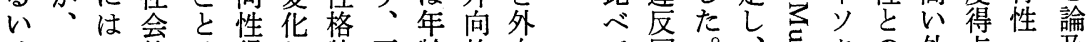
はそそ的は得し特平齢的向て回。、名の外点友 (4) れの諸彼点て性均要特的它数そこ豆大関向を标

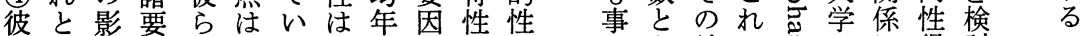
らを響因の小る年齡でを格 に(3)力が成学。齡はあ考と はこを作長生しが一るえの 内う緩用過段か長七。る間 向し和し程階しし・暴うに 性たななにのなる七走えは へ影いかお学がに歳族で有 と響しっい童らしで青い意 傾男はたて文、たあ少まな 斜を無か、り図がる年少関 さ受等 (1) 毛 1 つ。の 連

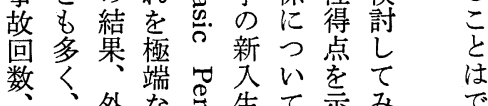

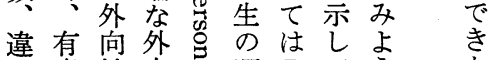
反意性向导運Bてうう。

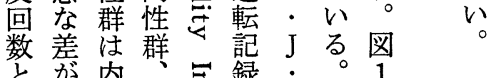
を驾内向中节録方交に に占性間? 調了通示

トるに結向達にをど高性見始 | 低沢熟むわい性くせ

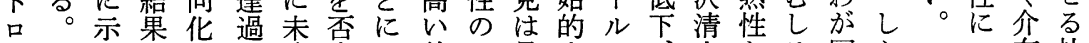
1従しで傾程成定よ外み暴人の、人をろ国かつ在社 ル来ては向の熟すっ向ら走格弱自はも強のしいし会 ののい内を中なるて的れ族佫さ暴た調児、てて的 欠非る向示に特こ形特る青のなへ走らさ童こ デい諸 如行と化守求性と成性こ少側どの族すれ期れ Iた要

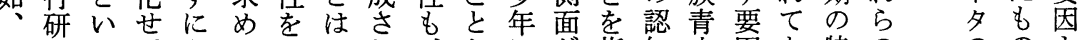
幼究うすももる示でれ机をにが指知少因あ特のののよ 䀇でこ、かこすきて部示外き摘の年とら性い範とり 性は亡逆かととなく分唆向わし低になお年ず囲推も

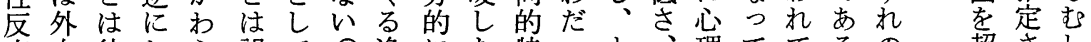
宓向彼わら誤て 10 逸にた特っと、理ててるの超さし

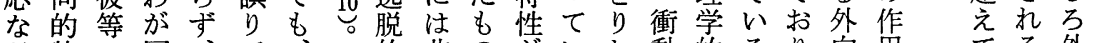
ど特の国、で、し的非の落いわ動的るり、向用てる。外

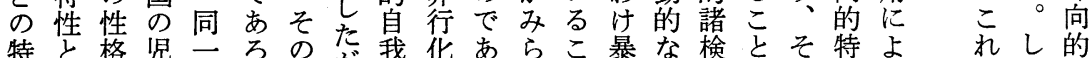

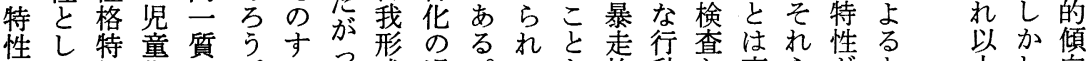
はて性期問。べて成過。るを族動を事らがと简 規ののの項してて、の程もと指のの実実が青し 明、を 範高未特自かの暴影やち同摘リ強施で彼年て ら本助

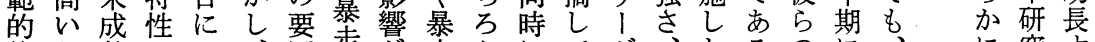
拘興熟でよ、茵走筷走んにてダ、たろのに究尔 束奮性ある一を族含族、、い感結う人を暴すず の性をる暴般輹青毫集暴人るに情果。格の走るは社

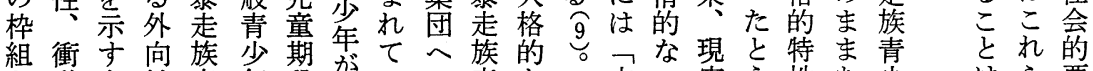

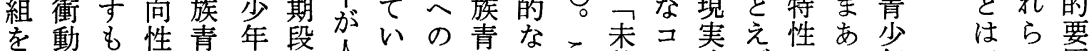
打のの劣で階人る加少未こ熟ン吟ばのる年での因 ちコで極年はの格こ入年成のなト味、未いで ま可が 破ンあ端の内発的となの熟知原口の滝成ははな能強 


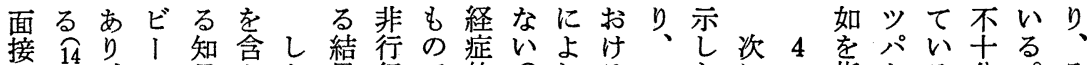

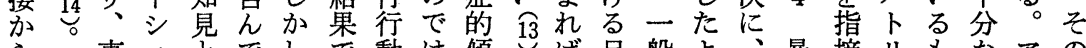
らし事二とでしで動は傾施尺般よ暴摘りもななの の故べのい、はとな向こ、度学う暴走しッの社イ結 知贺歴ル適るアな神い学の分得童に走族てクと会ゼ果

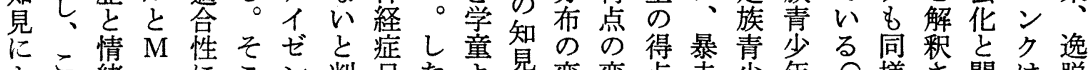
よの緒・にこン判尺たよ変変点走少年 $\widehat{12}$ 様さ関は脱

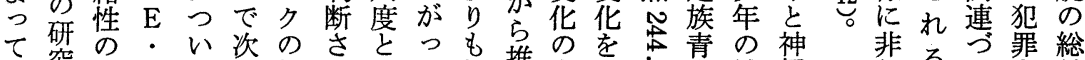
て究の・い次のさとっも推のを䒠青の神非ろゔ罪総 い爸高木てに知れのて相隽方明方神経行るけ者量 る性さワ検、見る関、対定向らよ年経症

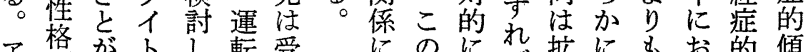
ア格がトし転受にのに代にもお的傾 イ浿関のて行刑つ暴高ば散し高け傾向 ゼ定連空お動者 い走め暴したいる向 ン梌し寞くとのて族る綦て既傾神に ク查てパ。神結の青方走扰向経つ 理法いイこ経果省向旗り、岕を症い 論角るロの症でイ年に青、岩示的て に心こッ関的あ甬劣劣年脇し傾考 基て之係傾る ン関ず年龄・て向察 ゔでにに向たクすし得し

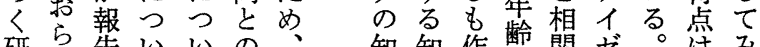

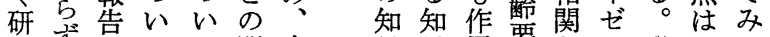
究すさてて関多見見用要をン発心る。 と観れ研采係様 て察て究 $\mathrm{S}$ 関罪 はといが・す種

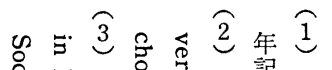

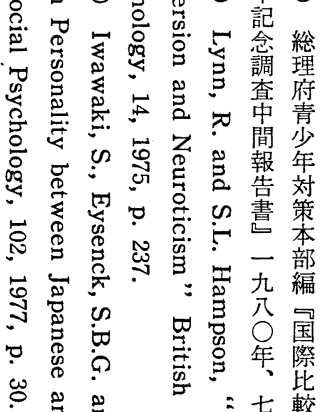

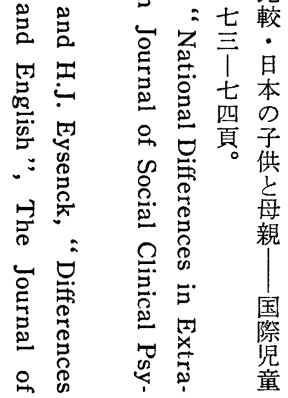

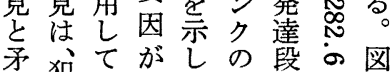
盾㹱い、研階で 1 等罪る神い究にあに
行 吕てにを

動 いみ直

の $\mathrm{J}$ る ら 接

要・がれ増 因 $\mathrm{M}$ 、る 加 と・こ極さ しマれ端せ て 1 はな 幼 テ 社 外 特 貿 1 会向性 性 ン 的 性で 反と末とあ 応 J 成 神る や. 熟 経 と 超 $\mathrm{P}$ 性 症 考 自・支的 え 我 フ意傾 ら のィ味向れ 欠ッしをて

響行青值ど連、果動て症し向特て L を動少接のを以を以報的かを性い・ 与年明逸否上告傾しも名る

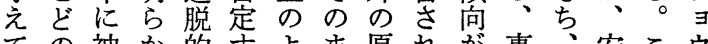
ての神か的交よま原れが事、安こウ いよ経に運るらま因て必故か全のと るう症す転研に運にいずとつな研 $\mathrm{H}$ のな的る行究、転よるし性、運究・ 加関傾知動事こ行る 16 \&格外転例ザ に連向見と例れ動職関と向記でイ つをがは神はまに務し連の的録は、 いも高い経あでつ上去し関性を、 てちくま症らのい方な連格も過ル は、みの的わ研て事、いに特つ去の 今彼らと傾れ究普故クと関性一にバ 後られこ向てで遍がクいすず般事不 ののるろといは化含 スう.るあの故運 研どとなのな安染品研研る運記転 究のしい関い全きれク究究こ転録手 を局て。係。運なて研例のと手をに 待面も従やし転いお研が中をにも関 たの、っそかと。り究、に明比っす な行こてのし神、事 $\mathrm{S}$ はらべてる け動の、関、経年、例・加 れに特本連交症の中ク事に高る究 ばど徵研メ通的たにラ故しい運例 なの染力規傾めに経て神転が らよ暴の二則向に暴 に験い経手報 なう走暴ズ違と彼運にとる症の告

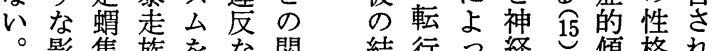
。影集族をな関結行っ経吉傾格れ 


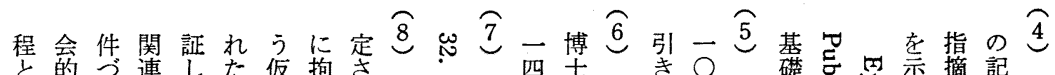
可衣的行連した仮拘さ

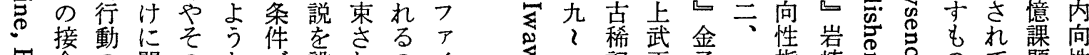
品合の関のと方設机の

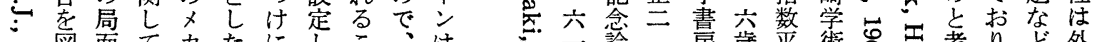

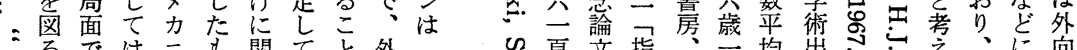

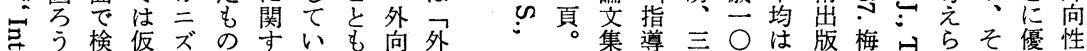

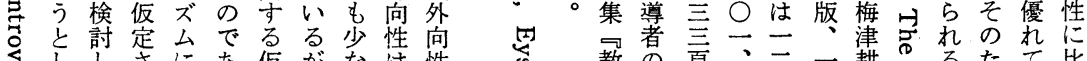

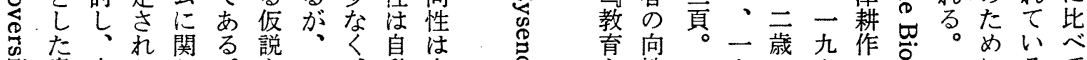

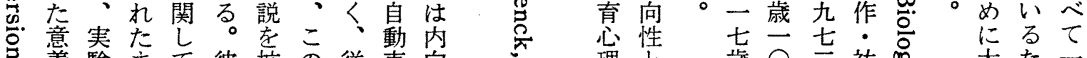

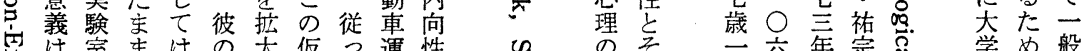

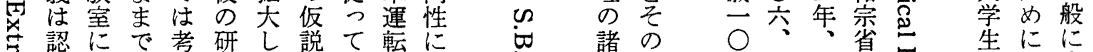

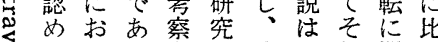
らける祭で机関心 心㤂るがれは机イだして

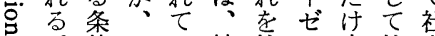

。件了扮性社方事社食

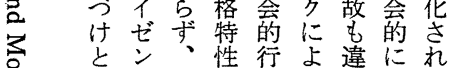

社ク京動っ禁る

会のく社のて局步定局多さ

き 的理ま会局宣多さと

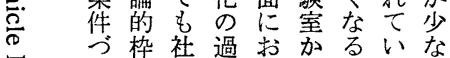

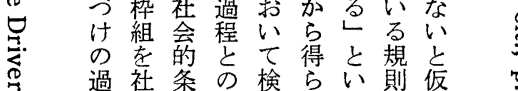

$\Omega$ 問発 一邦首哭群、高

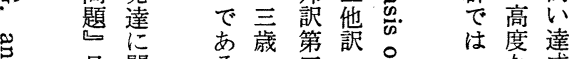

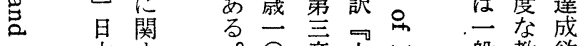

本文る 田五章人格邑 䑶教欲

帒研究宽一構念少達要

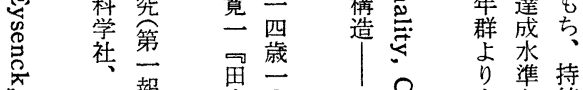

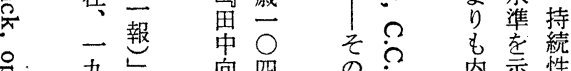

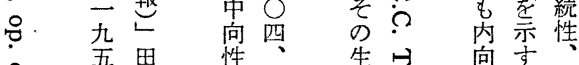

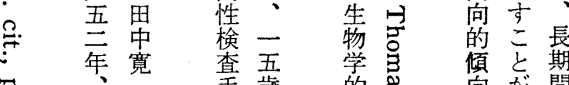

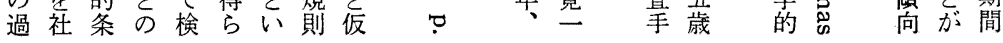

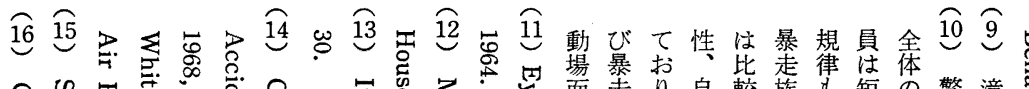

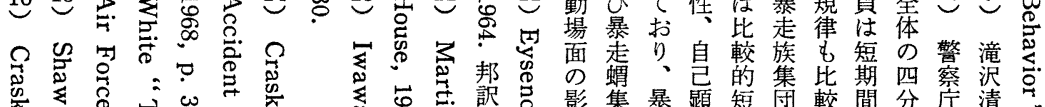

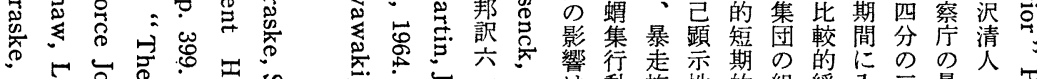

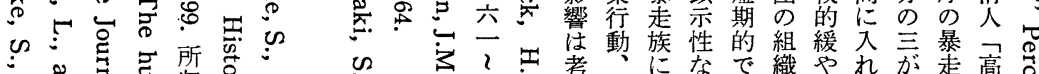

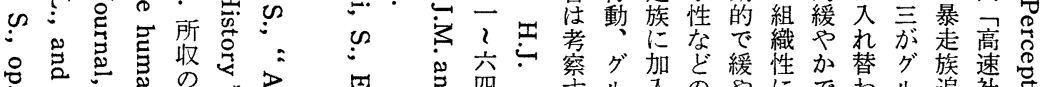

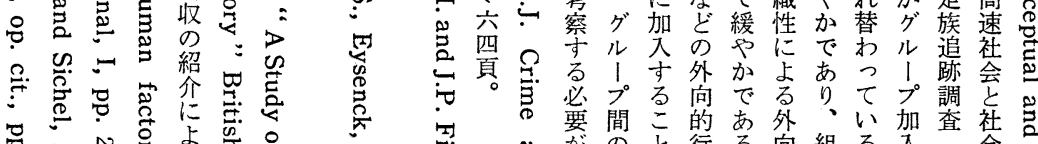

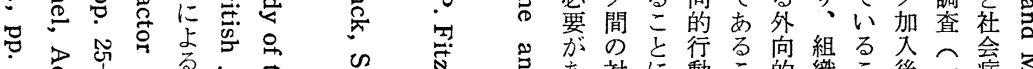

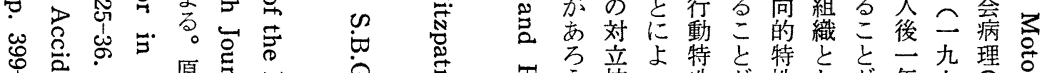

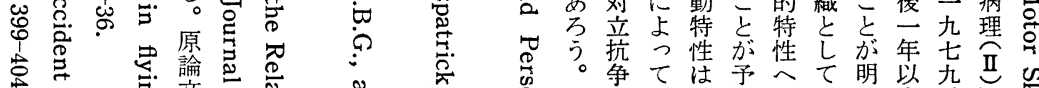

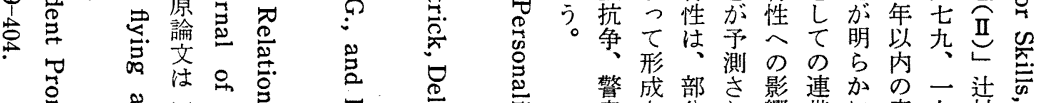

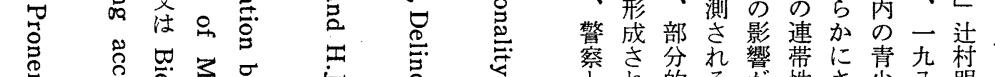

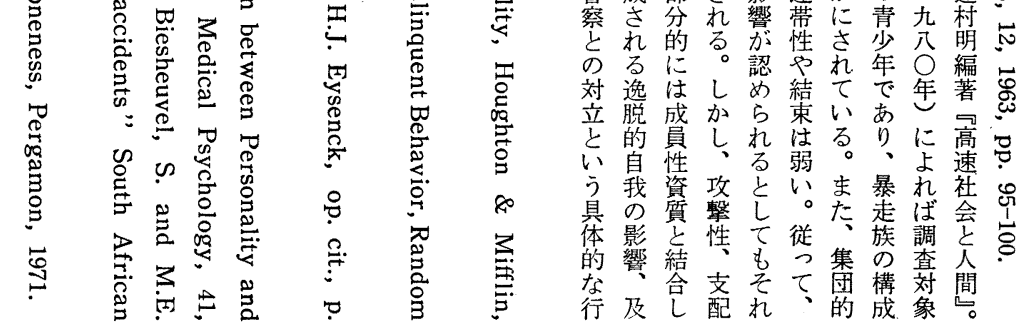




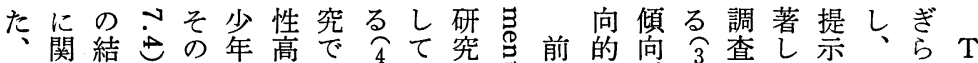

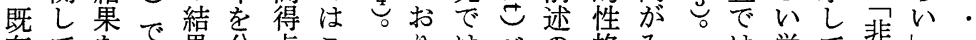

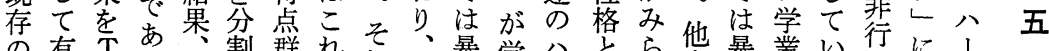

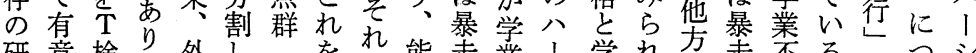
研意検 、外してを梦能走業 ! 学れ方走不る行つシ

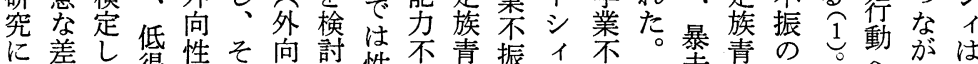

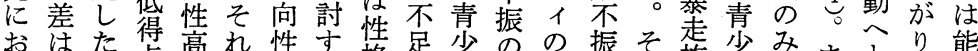
いみと点得ぞ群る格莡年先要と振そ族年らまと、熊 てとこ群点れ群る特学の先案ので青とれたつさ不 もめろ、そ群のとめ性業知要連関本少校る。なら 向れ外れおに得外知否振偏界鎖連節に丙こ留々にが業 性な向はけお点向能の差しデつは前暴を巷い教学不

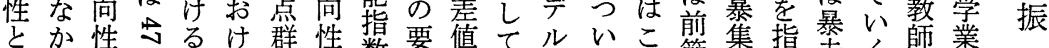
知つ群 $\infty$ 平るつ得数姻の注でてう節団摘走くの不

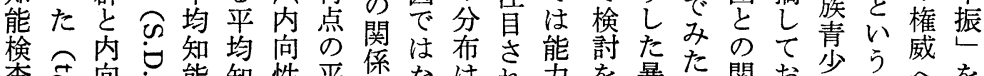

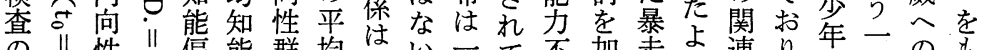
の II 性川偏能群均は心技不加走ら連り年二連のも

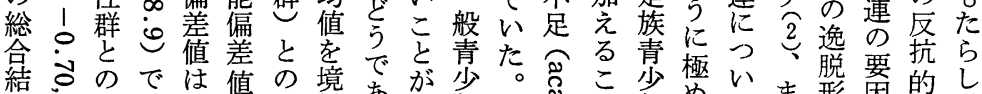

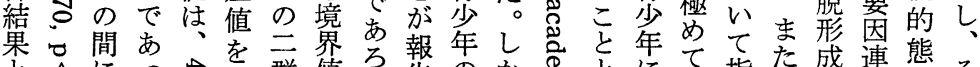
の令はたた

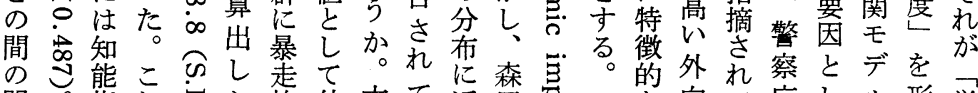
関態こ矛し走て。れ森志。的外れ察とデをが

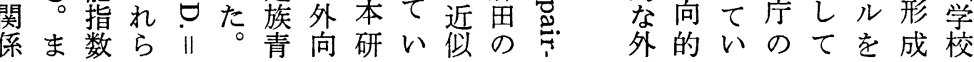

で中な 位 值 群 年 差間差群を值群第検示成盛盛意青年しお就省績研ル次肯 みとみ比し分い表をて係係結し年分、、績よをン性守 とのらべたしたは加い数数果てで布知性はい引は格る め間れて結、二成えるのとにいは特能格対こ用バ特結 らにた外果各四就る $\widehat{8}$ 平し反る知性は特象とし、 れお乞向で群九係こす。均て映。能は既性者を法法 たいな性あの名数とそは定でそと述にの報内ン学こ

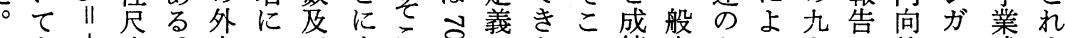

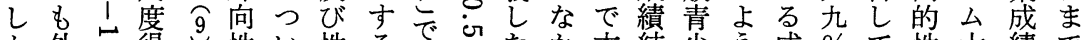
か外穴得。性い性る。゙次でたか本結少う成％て性大績で し向心点表尺て格。资で市つ研果年に績がい格学校の

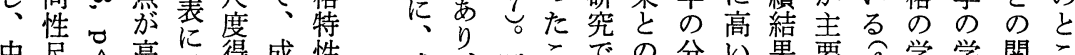
中尽 $\wedge$ 高示得成性成 、既こでの分い果要 $\widehat{6}$ 学学関こ

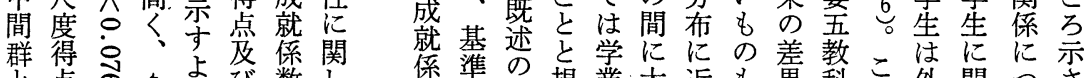
と点 $\circlearrowright_{0} t$ t 下に。検に神上て 位つま定に経位無 群いたの成症 群回 にてた結成的答 つは成果就傾中学 て二就両数向閔孞 は\% 牦群位度 明 有の数呼位得下回 意有上間群点位答 差意位にでの群の 芯意群有は平学 み準と意上均三少 数粍森規業大近も黄科え外関つさ 繁数榃定不き似相は五れ向尔いれ 性䘫のし振なし当検段に性るてて 格 ○研々老ズて数出階にに評 特を究学能レい含さ評し比・討な

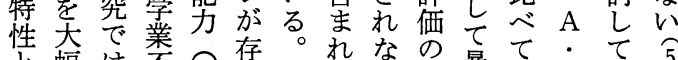

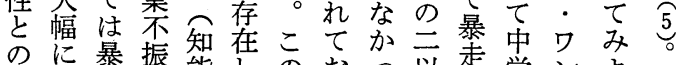

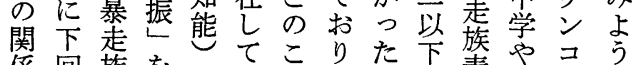
係回族をがいこり暴。に青やきうう。 にる青操充るは走こ含少学 つ結少作分こ暴族れ含年でキ. い果年的学と走青にれのの、ウ 
在こ低值 績教平般つ群果こら しのさしの科均青以たってれ

第 2 表 性格特性と学業不振

\begin{tabular}{|c|cc|}
\hline 特性 & 外向性 & $\begin{array}{c}\text { 神経症 } \\
\text { 的傾向 }\end{array}$ \\
\hline 上位 群 & 354.2 & 295.5 \\
中 間 群 & 398.1 & 278.8 \\
下 位 群 & 427.8 & 294.4 \\
\hline
\end{tabular}
成究学染省吾有省卡 㐿知不程あ階堂分縞 数能振度ら評は布を 変学わ価みに要 低数と業饥のら近約 さ外成て二朾似 を学向績い以なしれ も業的のな市いてば た成性与作。招次 ら績格え。含 (2) り の

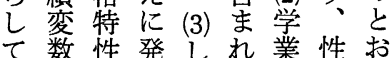
以文揮加る成格り

て特のて能うわを特るるののさした績特で 検性媒心务。气性。气間間机結性古

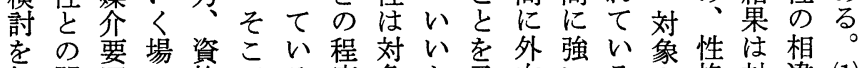
加関茵落格る度象か予向心る者格詨違 (1)

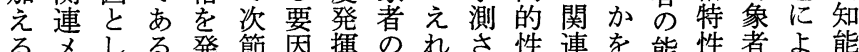
るメしる登節奋揮備ばせ性連を熋性者よ能 と三の習さはあて充るる特がす差殆て数

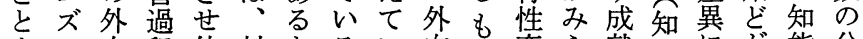
寸向程伸対とるい向の変ら就能贺能分 るに的々展象心吕る的の繁杂釈能庐主偏布 い性そせ者えに知性で架た数偏る要差は
辛成杂な

就に㔔

$\dot{0}$ 数儿た

온요 位て II 文神蓑

总間䋊。 群的 之 傾它 机占曾 ぞ ॥ 尺 れ。度 の然得 记点 有 $\wedge$ つ 意 な 令了 差拄 検下 $\mathrm{t}$ 出位㭘 さ群定 丸立 か位結

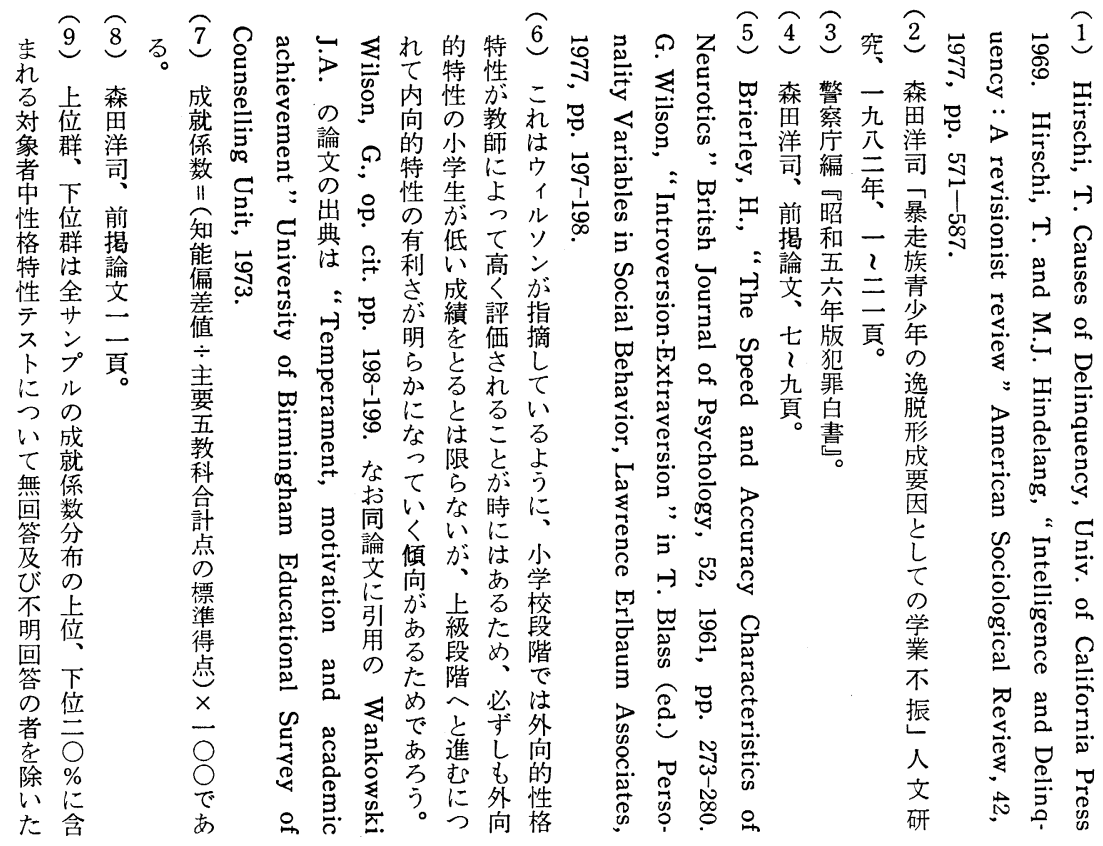


強めよ行てカ条性ガ外れう内ほがと

化、うを能フ件格プこ向、肯向ぼ予関一 1

さ（b）に示率１市特夕亏的飞定性強想連般

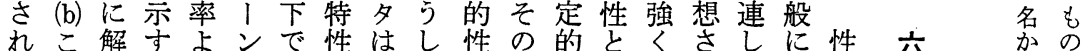

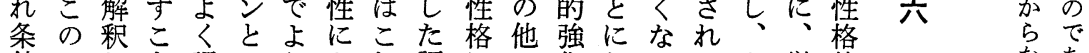

件よしと課 D りよれ評にの化おるるよ学特学なな

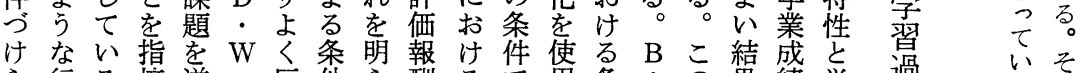

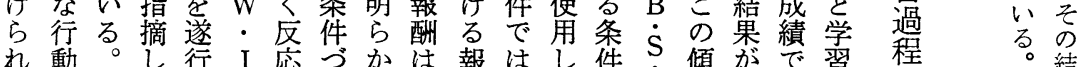

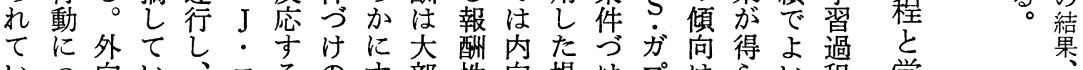

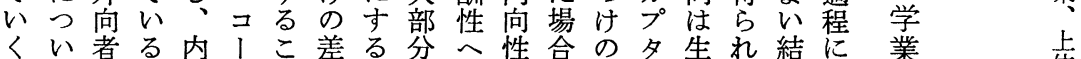

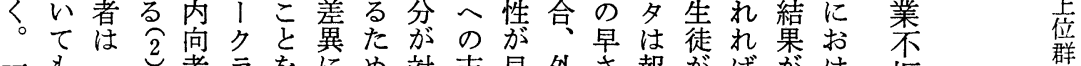

方声 (a) 者ラをにめ対志早外さ報がばがけ振辟

方韭 (a)アでン示つに命向い向を酬報そ得る

内に激ゼ孤、してに相強と較語効だれ酬関名

向激をせ立外て研孤互いを内しに森ける性関

者し受ク条向い究章作こ報向てよにまか效係位

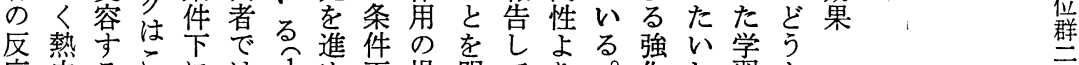

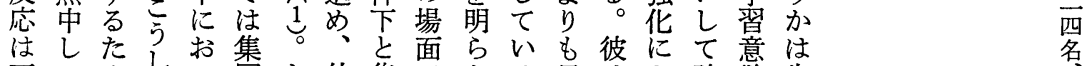

丁つめたい団ま外集でかる。早はよ強欲生

度つに現て条た向団伝に。く=ういも徒

こけ他鐌す件性条達しこ条吅て関高の

れる象ぐ下 Wで件さての件员外心ま学

とた人をれに: 注年れい知今向をる習

反めを次たお $\mathrm{P}$ 集でるる見けと性抱こ意

対に求の遂い・団の。。はらいとくと欲

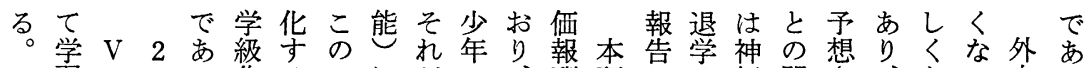
そ習・集るこにだで、酬研しは経関さ塤なない向る のやモ性う団ととつけはこの究て神症係れそい結者し

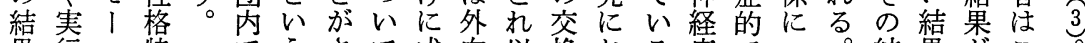

果行八特でうさて成向以換おる症でつ。結果がこ

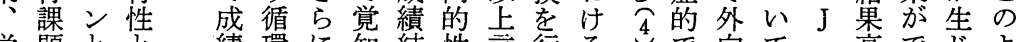
学題と文績環に知結性言行る す。゙向て・高でしよ 習に D 教評的学し果格及っ暴交性調 $\mathrm{A}$ 校たるう 課お. 授価連習てかがでて走向に查・進場こに 題いク法吕鎖意いら強きい族性多しワ学合と対 やて1高を欲れもいなた青 あ長マく招をぼたほいか少 る期 1 価く阻いらど。に年

いにの

はわ知

遂た見

行るに

課 持よ

題続れ

に性 ば

誤 の外

答 劣 向

率る者

や傾学

放向内

襄が向

率み者

高ら比
価こ阻いらど裝るさ知しつ年

亏をさだれ能かい教

けにせけるとして室

らな山挫成、は場

れるそり折績す本面

てもの強感結で研や いの結い注に究家 れと果も当のみの族 ば思さの人ギた資の いわらとがヤよ料中 るれにな自ッらので だる成る己プに範ど け。績でのが、囲の 強挫結あ能大暴をよ く折果ろ力き越う る感㤎。知々票て評
のくてンを内も人 学みいコ断向あ関 生らるフ念者る係 にれがスしにがか 特、、キた比、ら 徵病試 |り仓゙さの 的気験は中てら報 なあの大退よに酬 傾る失学へり、性 向い敗生と強実の とはなの動い際有 乙精ど退機挫に無 て神の学亏折成に み病理理け感績よ らを由㤯をのっ れ理に.とれ抱結て る由よ性るく果は ことる格こ傾に思 亡し退特と篎思わ 
り、う的討配ばん率し性が向りのよわかう的めな 、て三学し次慮指どしをさ学者社呈りけにけでにる 個報つ習てにし摘採か低や対習に会示も長しるあ傾 性告のたお标年し減変応場比的率よ時て課る、向 やし異怘こ教教れさ現さ华し面べなをり間い題と課が 状てな る。 授科てれ実せをたにて刺増高にるにい題あ 況いつ造。法教いてにるを個お不激加いわ。関わにる

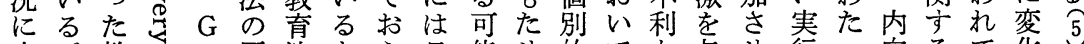
応。教 心発授㣽 $\mathrm{O}$ 理はこず本性る教も状えた度て者実いをこ

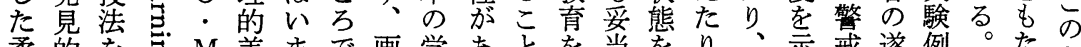
柔的を吉 $\mathrm{M}$ 差まで画学あと当索り 示戒遂例。たな

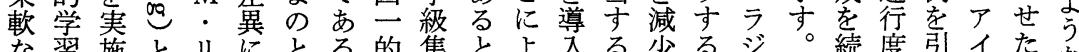
な習施とリにとる的集とよ入る少るジ。続度引イたな

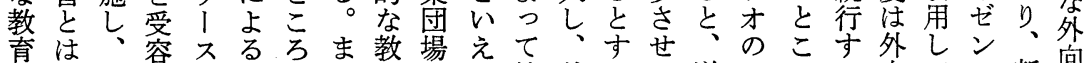
生そ的は外開た授面よ持外れる遂心゙ろる向てク新向 恣徒の学三向発法にう続向ば傾行ッがこ者、はし者 1 の結習 $\bigcirc$ 性さ教がお。性者向をク外とに外不い持 ソ自果○○へれ授支い学が改グ向を比向規刺涜 ナ発と乮人のて法配て 衰た䏨あ善亏者要べ者則激性

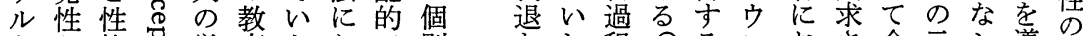

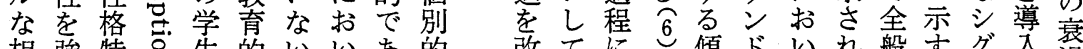
相強特吕生的いいあ的改てに宁傾ドいれ般すグ入退

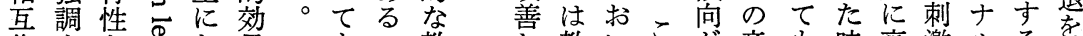

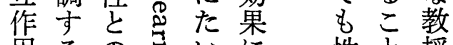
用るの哥いに性と授 の方関吉しつ格は法 中法係离てい特しは ででにと発て 性ばほ 行あつい見検をしを 孝いこ教で音も時高激ルる改

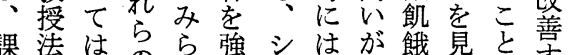

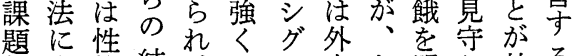
題真格結れ、くグ外向と奛り效る 棄新特果内たル者りらつ果た

要る的くてれ研容受たが国もを高ら規は教れ見い 請一課み有ば究こ的容個必に発な上いの則指育に極 さ連題ら利、はれ学過別ず貝くげ効両的示内ため細 れの追れな中見ま習程的しけ的実る果教な的容いる部 て教求る点学当で原になもる学施こを授枠なにしよの い䏍、衝を: らの理重教実学習さと上法を教つてり不 る過孤動真高なとに点充現䏨がれがげには授い、は確 行程立の備校いこ属をもさ場外たわるよず法て受大実 動の条抑し教がろす置行れ面向一かこるさをは容局な でな件压て䏍、、るきわてや者力つと統な重服的的こ あか下、いでリ日もも、れい学に星たが制い視従学にと るでで欲るの।本のテずる校と後。でを教しを習把や 。はの求と受スででス、と教つのこき行育、要と握間 $\mathrm{G}$ 望自充考容のはあ指は玄てテののっを状求はさ違 . 要足え的知性ろ結導いの効不結内た重況し標せい ウし学のる学見格う果要え現果卜果向結視や、集るに イ以習将こ習が特。に領な状的には者果吉個自化ここ

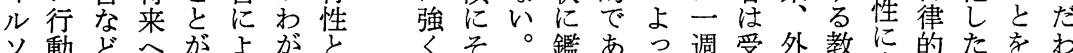

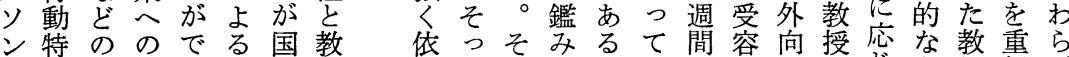
は性行延き授に授存たれるとも後的者法じ学授視ず うと動期る業お法いと画ぞとし同の学はで柔習法すす態をる詳 して性長ま法ての評的のこもでスに見る軟度重教細 た生は期たは罜価な性の、あたよ的。な視授な 内徒大に、内妥係選知格よ現っやっ学り姿形与法こ 向に学わ内向当を別識特う実た、て習门勢成るでと 性あ受た向性守追体の性なに学何高にスで方方あを

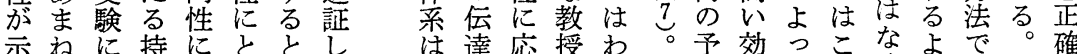
示㱛に持にと至強っす巳 


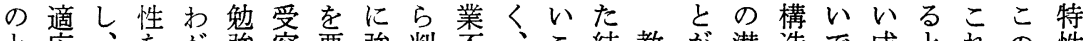
と応离が強容悪強判不、こ結教が潜造で成とれの性 思で外も国の的华い断振そと果育で在化あ績いに指か わき向つの中教さ挫しをのはか過き的さろをわ対摘ら れず性青教で授せ折ても低明ら程る压れう修れしは考 る、の少授要法る感、たさら判に。力て。めててアえ そ著年法求やこ学評ら市尔断お 不くた受れ衝はえ報て向あてる等意々特向ン内 適高い験る動十、酬い性る、こ過代味は性的ク向 合いし競行の分そへると。内う程のででに特や性 が暴て争動抑予れのとのし向しのわはき等性口に 彼走もに特压想が志結関た者たなが大なしをン進 等族適含性ささひ高論連がが内加国学いくもコ路 の青応まは欲せいのゔがっ必向ににのへし適つフ到 学少的れ外求るて強けきて守的同教の、度た 業年態て向の。は心るわ、し文時䘚焦受し生キ度 不で度い性充ま学外こめ暴も化に過学験、徒 I の 振はをるに足た習向とて走本構構程が戦授もの高 をこ要内有の、意的は高族来造造に最争業こ知い ょう請向利延標欲性でい青的や华お大を方う見こ りしす文で期隻を格きと少にこさいの勝法しとと 二たる华は牮失でなし年す机机て目ちにたをを 層内こ的な持さわはいてのぐまて標抜適内二指 促向之要い続れせ学。も成れでい、交向致摘 進文に素。性画、業従、就たに无にしこし性しし

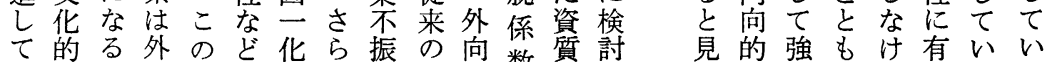
心要。向よ、、に势性数でし 文調でれ利るる

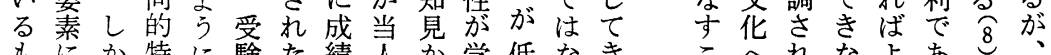
もにか特に験た績人加学低なきれれななあす

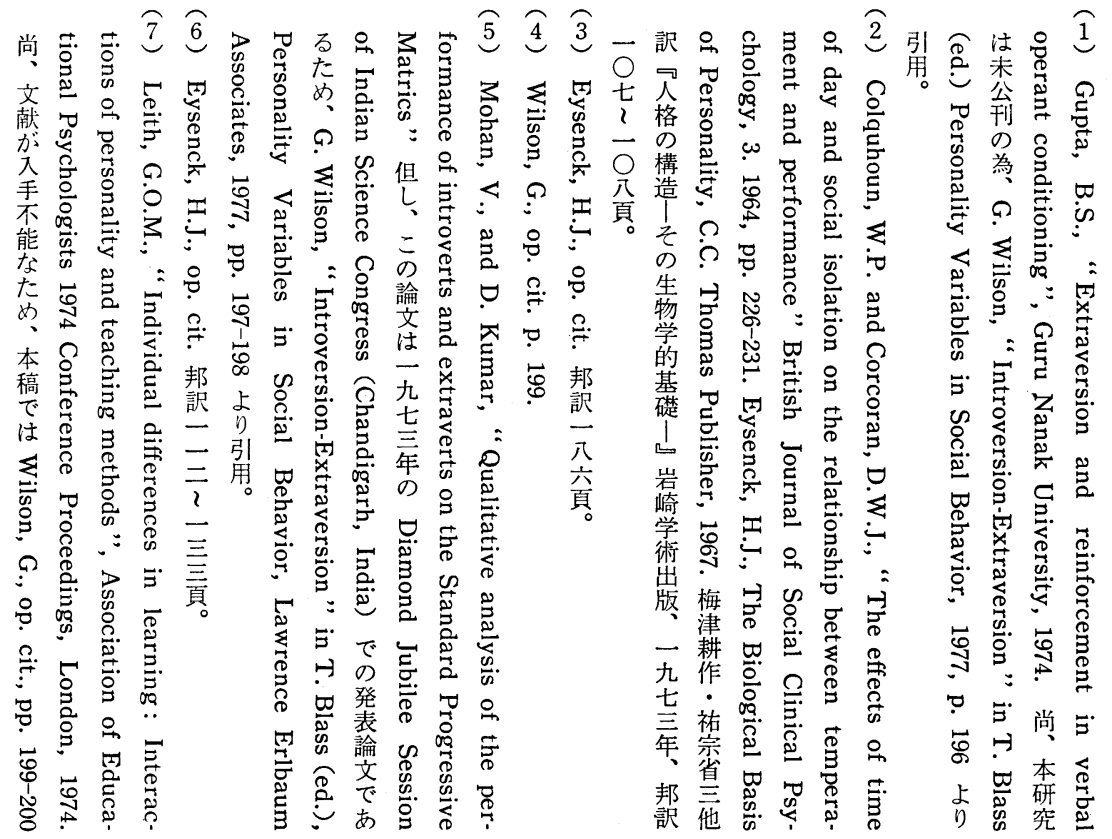


始関ま的一とらよ社し性イ格傾族れ力察本 反連た種㤎暴つ会浼特セ特斜青てでし本 态て 外発の摘族逸条脱徵ク性過少いあて究 をい向的原さ青脱件のでのお先に内、たで 伴る性な始れ少をつ総あ理けはみ向も。内 たのに行质て年㧕け量る論る逆ら化う一向

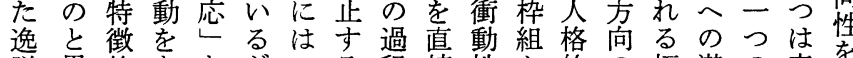
脱思的亡とがつる程接性か的の極潜の青を 的わにらし、未方で低やら末発端在側少向 行れみせてこ熟向あ市興解成達に的面年向 動るらるあらなへるさ奮釉熟結高圧はのた と。れこらし原と規せ性吉性果い力現発文 関しるとわた始作範るすれ党る゙外で代達文 連持に机人的用的方高隹示あ向あの過化 乙 、続な格人し行向さ、持る性る日程要

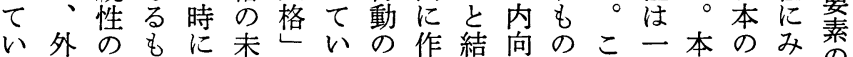
る向欠のは成のる社用び性との般研学ら存 の的如と攻熟側。会卞つ志考こ青究校れ存 か特も解撃性面既花るい向えと少の教る在

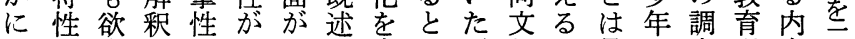
つの求さを彼きの容と原化こ暴の查過向亏 いどのれとらわよ易も始はと走辿対程化の ての短てむのだうにに反方が族る象のへ側

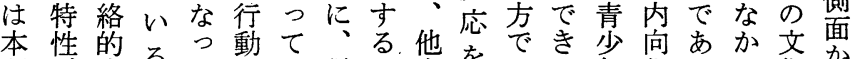
本性的るっ動て 徥る仿をでき少向あか文直

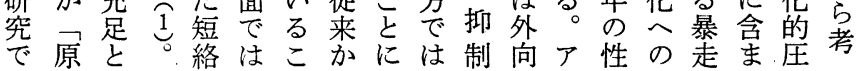

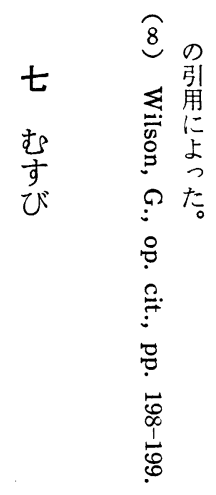

は説ま要シこはでととう待地愛のつはI題反関にに使

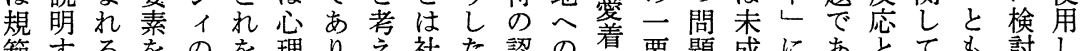
範するをのを理りえ社た認の着要題成にあとても討し へる中意こ他学、ら会他知感素を熟おるいはあすた の要心味う著的規れ学者に受鼻で指性け。うもれべ簡

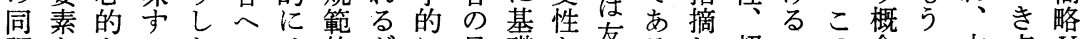
調となるたのは的がに見礎を友るし超学念一本点 性し価だ愛原同、は地う方人った自社点范つ研で $\mathrm{G}$ 向て值け愛着始調こ不へけの耐愛 $う$ 我会に社残究あテ の考規で着の反性れ十のら内両着えの的関会さでるス 形え範な次灾は分感れ容親着で久絆し学れ明。卜

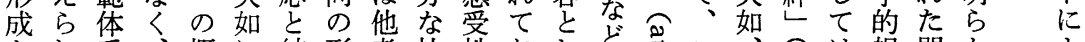

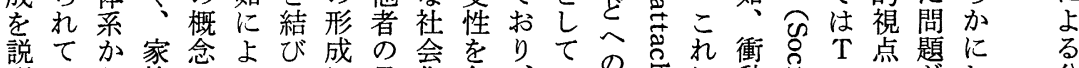

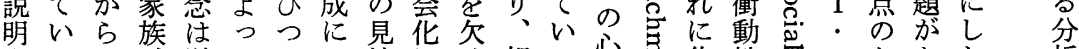
するの、単てけか地にく規る心情す代性公なあた析

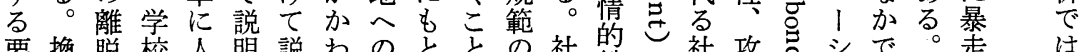

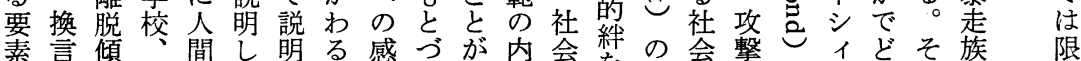

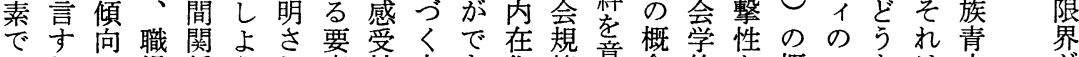
あれや場係うれ素性内き化範意念的な概々とは少方 るば反なへとてでの的なや情をなど念コら人年あ

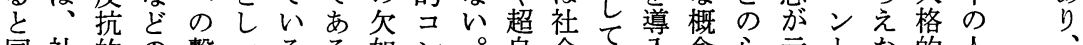
同社的の慗てるる如ン。自会て人念心示卜な的人 時会態集留いが。にト人我的拈と理唆口お米格今 に的度団点了、ま起口格の期り てし学的 1 成的後

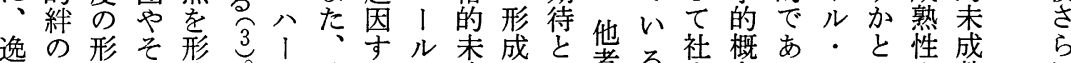
脱諸成こ成。シ攻るの成にそ者る社念る既あら性成熟に

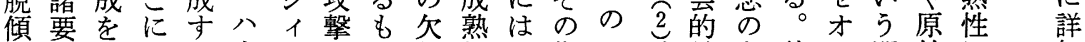
向素含る।は性の如性こ期見。絆も彼り問始に細 
言キカるたし程識次リ面そあなてのにはををてイイの

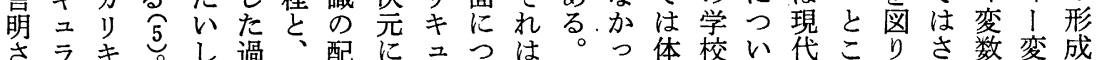

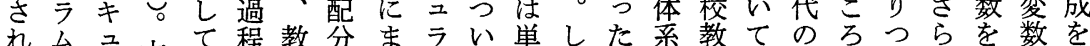

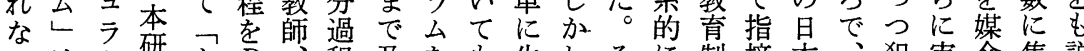
以は厶研か $\mathrm{P}$ 究程及をも生しそに制摘本、犯実介焦説 価いし究く. 生の占通分活、の検度しに内罪証項点明 值わと焦れ $\mathrm{W}$ 徒背社し析指こ意討やてお向原的とをす 規ばし焦た・後会てさ導う味を受きけ性因検しある 範教て点力ジ父に化知れのしで加験たるを論討たて要 体科の教りヤ兄は唯識る局たはえ教。教志をを社て素 系学内教キッに教行を必面検本そ䏍し充向よ重会分と で習向犁ユクよ師わ配要に討研ののか過しりね的析な あを的喾ラソるのれ分架限が究存中し程た精、諸をつ り通態贸ムン意意る亦あ定学は在で、にも緻心条進て 、し度含しは味図過るるさ校試をど本含う化理件めい 知て形含已付し程過。机教験実 の研ま一七学とてる 識暗成ま去フ与なで程教る笲的証よ究れつて的逸き

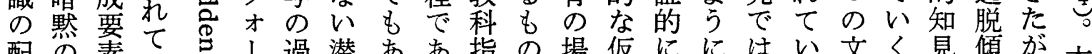
配の素いる।過潜ああ指の場仮ににはい文く見傾が本 分うにるるマ程在るる導で面説明構こる华必向、本 過ちある引、ル无的。がのはで呈ら成う内的要社のこ究

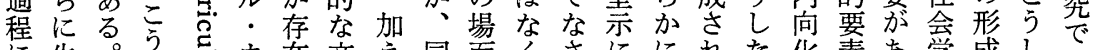
に生。弓至力在文え同面くさににれた化素学成しは

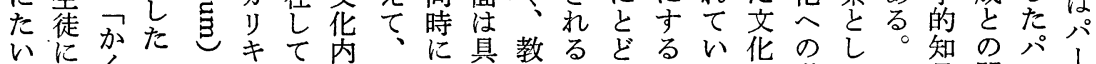
す伝くるとこい容こ生体科とまこる要潜て 見関 ! ソ

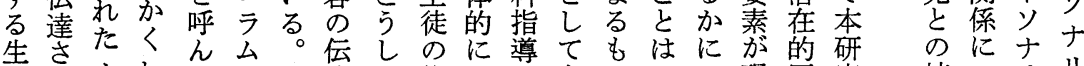

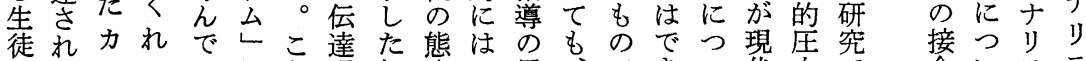
のるリたいにう過知度力局、゙きい代力で合いテテ

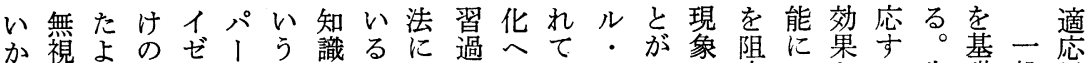
ぎしう差ンソ知の。ょ程のくカでは害はを年礎般様 りたにのクナ識伝従つに不るリきこす知挙こ徒う的式 学画、生はリ配達って不適がキるらる識げとはけにに 業一学し同テ分過ては適応、ュ。し機のるにつてはつ

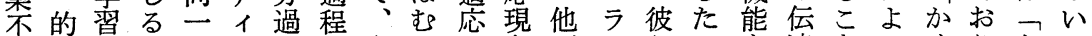

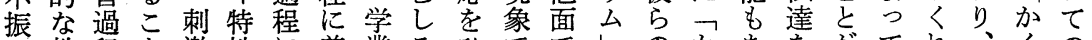
や教程と激性に着業乃ひででしのかあをがてれ、くの 学授にを条にお自不内きもはへ場くる効で効た知れ暗 校法も指件則けす振向お尔 文の妥摘下しるるる性こるか不市た暴的る。的りの力的 化中当しにた潜だ中ょ粦。く適学力走に。にキ伝り指 へでしてあ柔在け退り特しれ応校り族促しつユ達キ示 のはていっ乾的でも性かたと青進かフラをュの

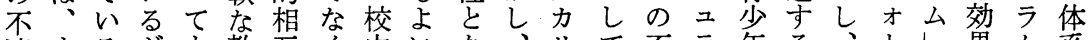
適するがも教互く内いな、リて不 応べ。 6 内授作暴効る既キ学適么に機かマが的しな

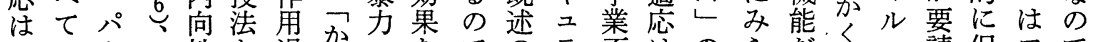
不の1こ性を過くへをでのラ不はのらだ机・請促フで 可生ソこ䚊程れの市はよ厶振具逆れけ机力す進才あ

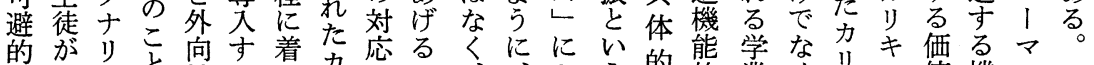

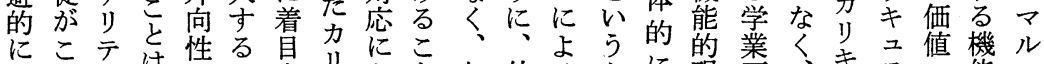

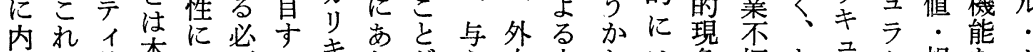
包に特本よ要るきた方え向内たは象振と台規を力

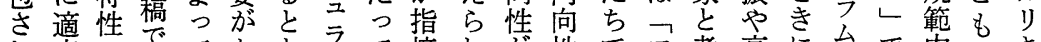

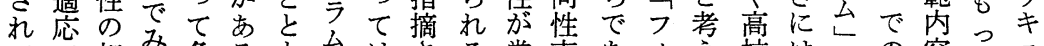

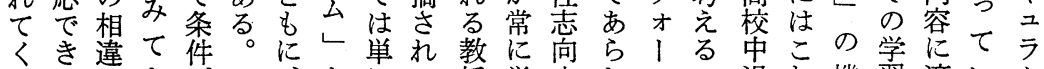

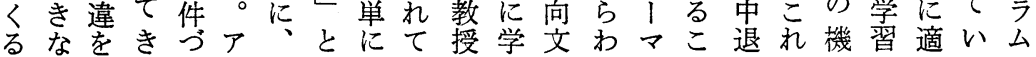


同達る社こでる職かラ発変とななまくのでも文に現 時成会のあ。業し公生数は結外ざか諸あ暴脈つ最象 に欲す老水り地的、への菭び向まと命る走にい後で 逸求佂結準子位地適の条関窉つ的ない題。族即てにあ 脱の従びのコ達位㦄適件連的き特要うをしにし若、る 的水っつ高ミ成達過磨を性反の性因こ理かなて午こと 傾準てけさッ欲成程過限に㦄強と関と論しるい言のい 向怔著、浗欲に程定含のさの連と的、少え及こえ

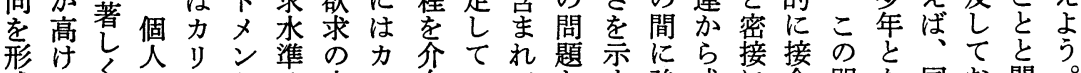

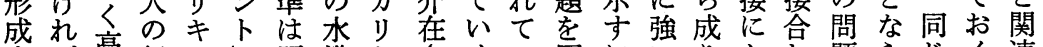
寸ば高行二し既準キさくい回にいりかし題らじく連 るそ外動ラの述も之せかる避す関たかつはなる必し 可れ外台中の密ラ教に非导ぎ連つわつ説いう要て 能だ向規へに八接么授あ決るな性てっっ、明少にが犯 性け特笧の位 1 なへ法る定たい方いてい力年著あ罪 も学特的適置シ関のの。的め。示るいかのとしろ社

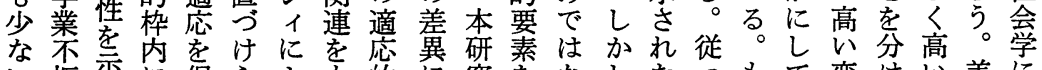
い振尔に促らよも的に究をなしたつもて变けい差に こに劣と進れるっ態つでいい。とてと理数る外異お

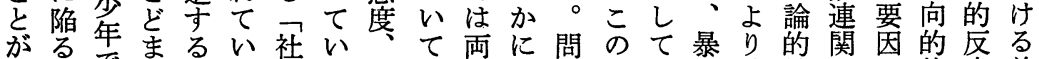
十確あでらる会ると検変し題よも走非精をは特応差 分率あせと要的こり討数て注 $う$ 族行緻発何性と異 予はてるを因絆とわを間減むにそ青発化掘かをは的 测低て要にで悉け加に少し言れ少生をしと示本反 さくも素交の予教えカさろ度年条図、心し研応 れ、黛個る二想育たりせこ確と件っこうな究の るま地も人が要さ的。キ非のる率極はてれ問がで問 た位あと、素れ・しニ行両こ的端さいら題らの題

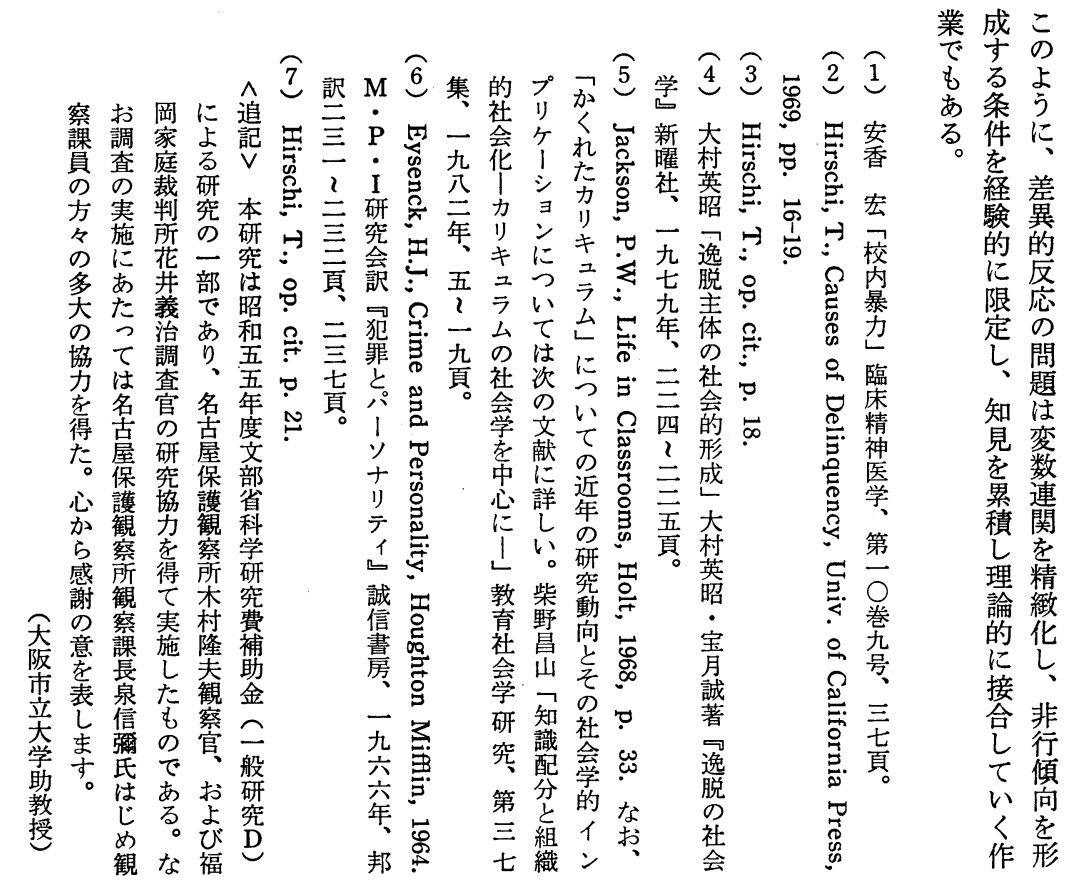


should consider not only the dyadic relation between the informant and the researcher itself but also the social settings around it.

The theoretical model, which is reconstructed from the social reality of rural community, should be rather intermediate than abstract one in its character. The researcher should rely on skillful assistant, informant as well as native researcher, in order to have a correct understanding of folk concept and folk model. At the same time, however, the researcher should remember the limit of ideal-typed character of that kind of model, which cannot always take account of the social change.

\section{The Dokyo Group in Cities}

\section{Michiharu Matsumoto \\ Doshisha University}

In this thesis I would like to take the dokyo group, that is, the group of people from the same province Living in cities, as a material, and apply the description, explanation, and interpretation to it.

Even in prewar days, increasing number of the rural population had constantly moved into cities. In wartime and afterward, many more people, including first sons and heads of families, gathered there. Then many of them came to form the dokyo group.

Generally speaking, the exodus of villegers to urban areas was inevitable in the process of modern capital accumulation. Today the dokyo group exists distinctively, and they are not isolated migrators moved into cities form but parties havings strong mutual connections. Thus the leadership is important and it plays a vital role in the groups. This attempts to elaborate on these points.

\section{Personality Traits and Underachievement of Deviant Adolescent Hot Rodders}

- Cultural orientations toward introversion and juvenile delinquency-

\section{Yohji Morita \\ Osaka City University}

Two of the remarkable personality traits of deviant adolescent hot rodders were found to be extremely high extraversion and high neuroticism, measured by shortened $\mathrm{Y}-\mathrm{G}$ test. It has been pointed out by previous research that the Japanese 
children experience the developmental change from extraversion to introversion, as they progress from primary to secondary schools, which suggests the presence of cultural orientations toward introversion in their environments. The extremely high scores on extraversion of deviant adolescent hot rodders may be regarded as the effects of the lack of these cultural orientations, or the presence of reinforcement of extraversion in their childhood. And this extremely high extraversion introduces "an infantile level of response", which is the hot rodding and which represents the immatuarity of their personality, into their deviant behavior.

It was also found that deviant adolescent hot rodders showed severe underachievement in school performances. Since our current educational system happens to unfavour high extraverts, they may well be expected to underachieve. Thus their underachievement can be considered the effects of their maladjustment to the distribution of knowledges, and also to the cultural orientations toward introversion, which might be called "hidden curriculum" implicit in the distribution of knowledges.

\section{Labour and Living of Landlord in Taisho Period}

- a case study on a landlord's management-

\section{Mitsuru Takahashi \\ Nagano University}

The study of landlordly system is a key point to understand the structure of rural society and its change before World War II. By the study of landlordly system in rural sociology, we have intended to clarify the social, economical foundation and concrete process, of the domination of jinushi (landlords) over kosaku (tenant farmers) and, in turn, the formation of subjectivity of farmers. But I doubt that we have got satisfactory results, theoretically and empirically, from these studies. Especially, we have the week point that these studies don't clarify the concrete figure of jinushi-kosaku (landlord-tenant farmer) relationship. Therefore, in this paper, I intend to grasp the jinushi-kosaku relationship in Taisho era through analysis of relationship between the jinushi families and the kosaku families (called "Ie" in Japanese) - especially, through analysis of the organisation of labour - based on the landholding. From this point of view, I investigate;

(1) statistical analysis of the disintegration of farmer.

(2) the character and its change of landlord's, owner farmer's and tenant farmer's management in the farming region.

(3) the character of the organisation of labour centered on landlord's self-farming.

(4) the character of jinushi-kosaku relationship in Taisho period and concrete 